\title{
EI Niño variability off Peru during the last 20,000 years
}

\author{
Bert Rein, ${ }^{1}$ Andreas Lückge, ${ }^{2}$ Lutz Reinhardt, ${ }^{2}$ Frank Sirocko, ${ }^{1}$ Anja Wolf, ${ }^{2,3}$ \\ and Wolf-Christian Dullo ${ }^{3}$
}

Received 17 October 2004; revised 5 March 2005; accepted 13 May 2005; published 4 October 2005.

[1] Here we present a high-resolution marine sediment record from the El Niño region off the coast of Peru spanning the last 20,000 years. Sea surface temperature, photosynthetic pigments, and a lithic proxy for El Niño flood events on the continent are used as paleo-El Niño-Southern Oscillation proxy data. The onset of stronger El Niño activity in Peru started around 17,000 calibrated years before the present, which is later than modeling experiments show but contemporaneous with the Heinrich event 1. Maximum El Niño activity occurred during the early and late Holocene, especially during the second and third millennium B.P. The recurrence period of very strong El Niño events is 60-80 years. El Niño events were weak before and during the beginning of the Younger Dryas, during the middle of the Holocene, and during medieval times. The strength of El Niño flood events during the last millennium has positive and negative relationships to global and Northern Hemisphere temperature reconstructions.

Citation: Rein, B., A. Lückge, L. Reinhardt, F. Sirocko, A. Wolf, and W.-C. Dullo (2005), El Niño variability off Peru during the last 20,000 years, Paleoceanography, 20, PA4003, doi:10.1029/2004PA001099.

\section{Introduction}

[2] The El Niño-Southern Oscillation (ENSO) is the major source of global interannual climate variability [Philander, 1990]. Whether, how, and why the strength of this phenomenon changes on longer than interannual timescales is therefore of broad interest. However, meteorological and oceanographical observations and sparse regional anecdotal evidence [Quinn, 1992; Ortlieb, 2000] report on ENSO variability during little more than the last century (measurements) and the last few centuries (chronicles), respectively. A flood sediment record in a small lake in the high Andes of Ecuador [Rodbell et al., 1999; Moy et al., 2002] indicates fading ENSO activity prior to $5 \mathrm{ka}$ (5000 cal. years B.P.). Cooling of the ocean surface after $5 \mathrm{ka}$ seems to be indicated by molluscs and fish bones from archaeological sites in northern Peru [Sandweiss et al., 1996; Andrus et al., 2002]. The significance of the thermally anomalous molluscan assemblages has been discussed intensively [Sandweiss et al., 1997; DeVries et al., 1997; Wells and Noller, 1997; Sandweiss et al., 2001]. The cooling of the ocean surface (after $5 \mathrm{ka}$ ) is ascribed to the intensification of the ENSO system with increased upwelling of cool water between El Niño events. In contrast, weak El Niño activity (e.g., not El Niños) was concluded from rather cool mid-Holocene SST near the Galapagos Islands [Koutavas et al., 2002]. A period of weak El Niño activity seems also to be documented in other geological [Keefer et

\footnotetext{
${ }^{1}$ Institut für Geowissenschaften, Johannes Gutenberg Universität Mainz, Mainz, Germany.

${ }^{2}$ Bundesanstalt für Geowissenschaften und Rohstoffe, Hannover, Germany.

${ }^{3}$ IFM-GEOMAR, Kiel, Germany.
}

Copyright 2005 by the American Geophysical Union. 0883-8305/05/2004PA001099 al., 1998] and archaeological records [Núñez et al., 2002] and is supported by modeling experiments [Clement et al., 1999].

[3] Most of the early Holocene and older records used for ENSO reconstructions rely on proxy data with multidecadal to centennial or coarser resolution [Diaz and Markgraf, 1992, 2000]. The majority of these studies concluded that during this period ENSO scale variability did not exist or that it existed in a different mode [Markgraf and Diaz, 2000]. However, high-resolution studies on ENSO activity during the early Holocene are still missing.

[4] During the Last Glacial Maximum (LGM) and Late Glacial (LG), the Zebiak and Cane ENSO model [Zebiak and Cane, 1987] shows strong El Niño activity [Clement and Cane, 1999]. Simulations with a global coupled ocean/ atmosphere/sea ice model (NCAR Climate System Model) by Otto-Bliesner et al. [2003] predict a weaker Holocene than LGM and modern ENSO. Over the last few years, proxy evidence for stronger El Niño activity for several thousand years after the LGM has grown. An El Niño-like zonal SST pattern was proposed for the Eastern Equatorial Pacific (EEP) [Koutavas et al., 2002]. From outside the ENSO region Rittenour et al. [2000] report ENSO-like variability in lacustrine sediments in northeastern America between 17 and $13 \mathrm{ka}$. Corals provide the highest temporal resolution of all archives and seem to be the most reliable recorder of El Niño activity in the past [Corrège et al., 2000; Tudhope et al., 2001; Cobb et al., 2003]. However, corals only provide short and isolated time series, so there is a significant lack of ENSO proxy records on all timescales.

[5] This paper contributes high-resolution marine proxy data for ENSO variability during the last 20,000 years derived from a sediment core, SO147-106KL, that previously revealed evidence of a late medieval ENSO anomaly [Rein et al., 2004]. Sea surface temperatures derived from alkenone analysis, together with proxies for marine biopro- 


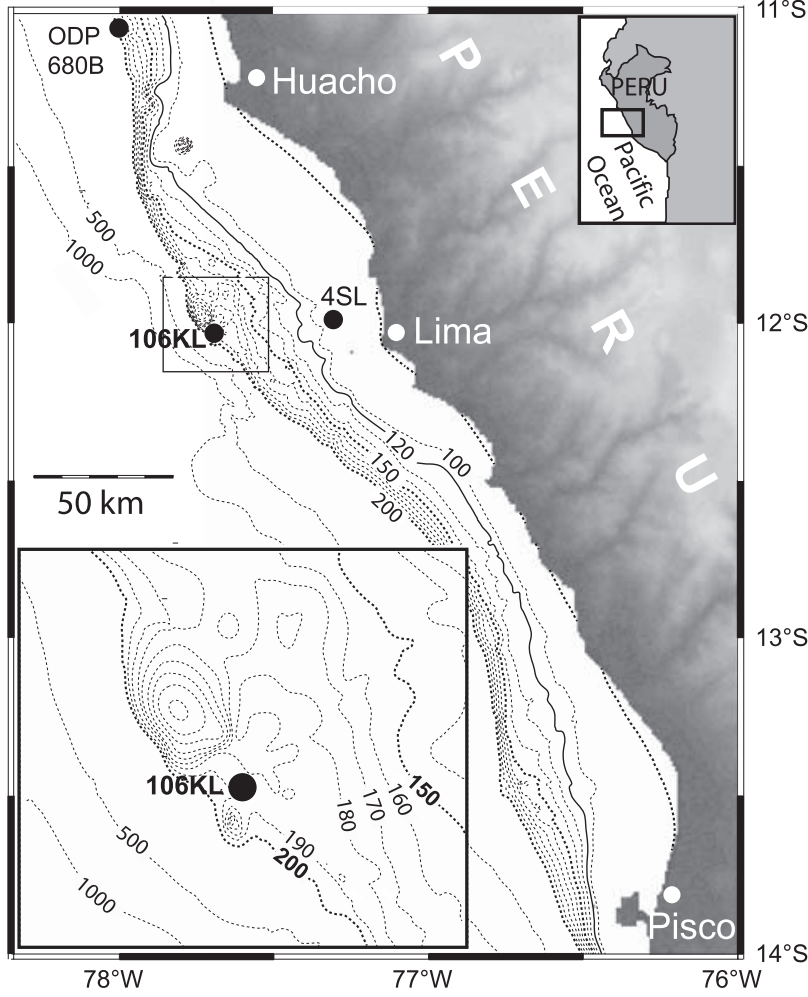

Figure 1. Study area with bathymetry, topography (GTOPO 30).

ductivity and precipitation on the continent derived from photospectrometry are used to monitor paleo-ENSO activity variations.

\section{Study Site}

[6] The study site SO147-106KL (80 km off Lima/Peru; $12^{\circ} 03^{\prime} \mathrm{S}, 77^{\circ} 39.8^{\prime} \mathrm{W}, 184 \mathrm{~m}$ water depth, Figure 1) is located in a small basin on the edge of the shelf. The paleowater depth corrected for sediment thickness was about $75 \mathrm{~m}$ during the LGM sea level lowstand. The basin is sheltered by a landward ridge (Figure 1) against erosion by turbidites and coarse-grained mass flows. A $20 \mathrm{~m}$ long sediment sequence (106KL) was recovered from this basin during cruise Sonne-147 [Dullo et al., 2000] in 2000.

[7] Oceanography and climate along the coast of Peru are fundamentally linked to ENSO variability. Figure 2 shows the position of 106KL below the warm water anomaly during the 1997/1998 El Niño event. Between the El Niño events, seaward Ekman transport of surface waters by trade winds causes extensive upwelling of cool and nutrient-rich deep water. These waters make the Peruvian shelf one of the most bioproductive marine systems. Organic matter decay causes strong oxygen minimum conditions between 50 to $650 \mathrm{~m}$ water depth favoring the preservation of laminated diatomaceous and diatom-bearing oozes [Kudrass, 2000].

[8] During El Niño events upwelling of nutrient rich water (and therefore bioproduction) is subdued by the deepening of the thermocline with the arrival of the Kelvin waves. Then upwelling is fed with warm and nutrient depleted surface waters and cannot reach into the cooler and nutrient-rich deeper water levels. The reduced nutrient availability is caused more by the changed chemistry of upwelled water than by the dearth of seaward blowing winds and the resulting reduction of upwelling itself. During El Niños seaward blowing winds and therefore upwelling may even intensify as documented by Arntz and Fahrbach [1991] in a comprehensive textbook on climatic, physical, chemical and biological changes in Peru before, during and after the 1982/1983 El Niño. Besides the reduction of marine primary bioproduction in the pelagic zone of the ocean, extensive rainfall reaches into some regions of otherwise (hyper) arid coastal deserts [Philander, 1990]. Precipitation runoff erodes fine-grained lithics from soils. These are flushed via rivers into the sea where they are dispersed over hundreds of kilometers along the shelf by the northward flowing Peru Current $(0-30 \mathrm{~m}$ of water depth) and the southward flowing countercurrent (below $\sim 30 \mathrm{~m}$ of water depth) [Scheidegger and Krissek, 1982]. The velocity of the undercurrent increased from $4 \mathrm{~cm} / \mathrm{s}$ to average velocities of $25 \mathrm{~cm} / \mathrm{s}$ during the El Niño in 1983 [Arntz and Fahrbach, 1991]. During strong El Niño events, the Peru Current reverses its flow direction [Arntz and Fahrbach, 1991], causing the southward transport of suspended sediments by both, the surface current and the undercurrent. Since ocean currents transport the finegrained lithics over large distances, sedimentary archives on the outer shelf integrate the discharge of riverine lithic suspension from a great number of river catchments along the Peruvian coast.

[9] Strong El Niño rainfall occurs especially in the northern part of Peru, whereas strong El Niño rainfall was less regular south of $11^{\circ} \mathrm{S}$ during the last century [Wells, 1990; Ortlieb, 2000]. In the southern part of the catchment area of $106 \mathrm{KL}$, in central Peru $\left(11^{\circ} \mathrm{S}-14^{\circ} \mathrm{S}\right)$, weak monthly precipitation maxima $(2-6 \mathrm{~mm})$ occur during June to September and are not El Niño related. However, these small rainfall amounts are not known to be capable of generating floods strong enough to disperse large amounts

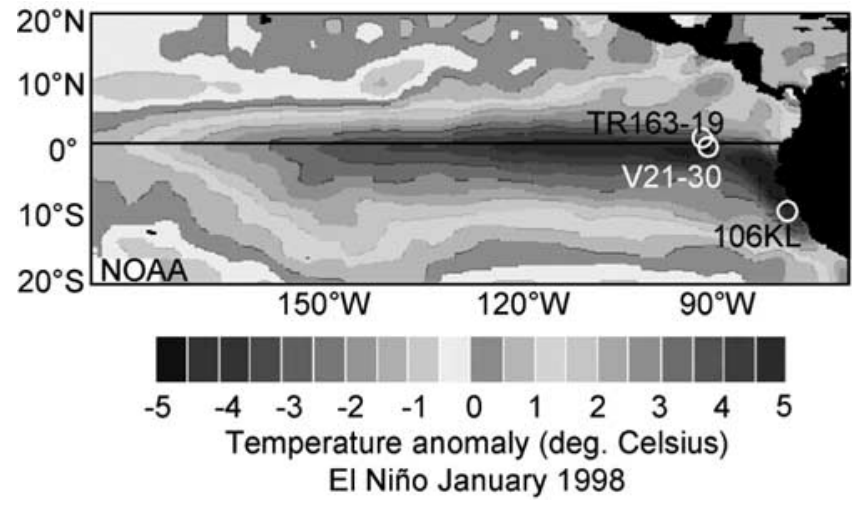

Figure 2. Sea surface temperature anomalies during the 1997/1998 El Niño (http://www.cdc.noaa.gov/map/clim/ sst olr/el_nino anim.shtml) and core locations of 106KL off $\bar{P}^{-}$Peru and eastern equatorial Pacific sites V21-30 [Koutavas et al., 2002] and TR163-19 [Lea, 2004]. See color version of this figure at back of this issue. 


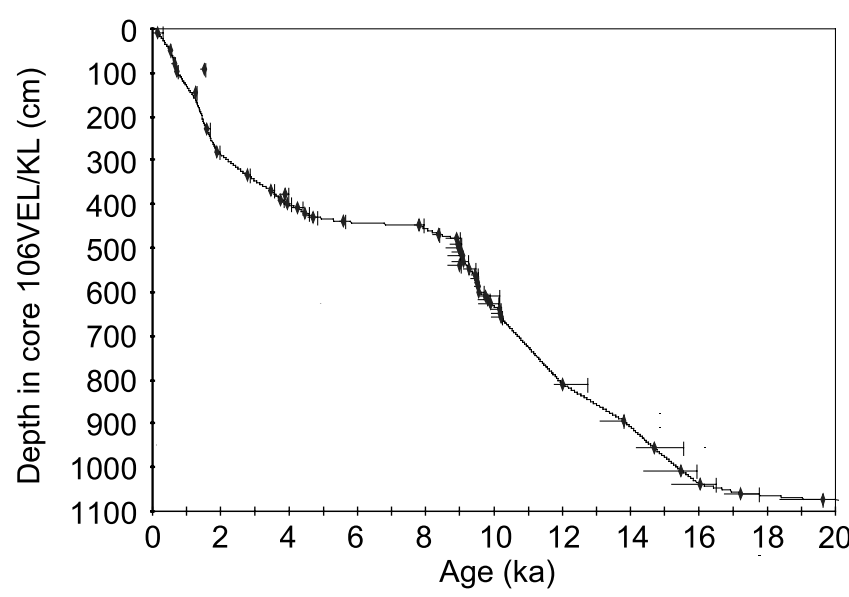

Figure 3. Accelerator mass spectrometer ${ }^{14} \mathrm{C}$ dating of core $106 \mathrm{KL}$.

of fine-grained suspended sediments over wide areas of the shelf.

[10] The contribution of eolian dust (compared to riverine sediments) can be neglected on the Peruvian shelf area [Scheidegger and Krissek, 1982]. Therefore ENSO proxies can be derived from peaks of lithic concentrations and from primary production proxy data in the shelf sediments.

\section{Methods}

\subsection{Dating}

[11] Dating of piston core 106KL used cesium and lead isotope profiling (A. Suckow, GGA, Geochronology and Isotope Hydrology, Hannover) and 45 accelerator mass spectrometer (AMS) ${ }^{14} \mathrm{C}$ dates (Leibniz Laboratory for Age Determination and Isotope Research at the University of Kiel) in the upper $11 \mathrm{~m}$ of sediment (Figure 3 and Table 1) [Rein et al., 2004]. Dating of the Holocene sediments is described in the supplements to Rein et al. [2004]. The organic carbon fraction (with the exception of one sample) of $\sim 1 \mathrm{~cm}^{3}$ sediment cubes has been dated since calcareous remains are rare in this area of high bioproductivity. Parallel dating of foraminifera and organic carbon on core material from an earlier cruise (SO-78) in the study area revealed no

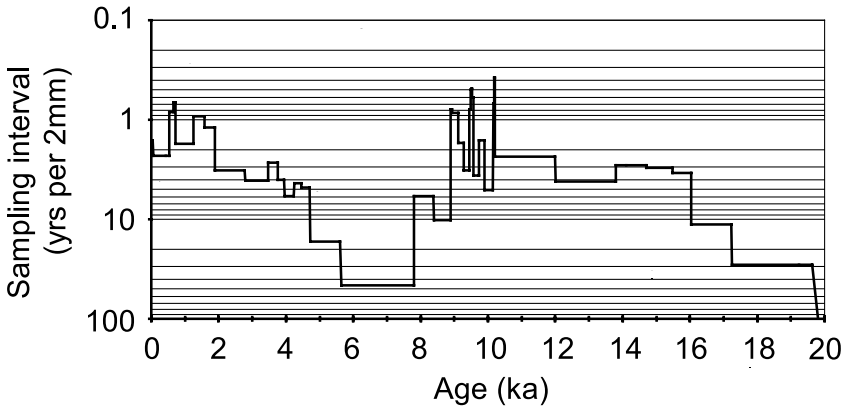

Figure 4. Mean temporal resolution of proxy data derived from color logging.

offset between the ages of both fractions (N. Biebow, unpublished data, 1998).

[12] The oldest radiocarbon age relies on molluscs (KIA 11814, Table 1) from a $6 \mathrm{~cm}$ thick layer where these are abundant. The layer appears as a strong reflector in all sediment echo soundings, also of neighboring shelf basins [Reinhardt et al., 2002]. This prominent reflector was dated to the last sea level lowstand in ODP Hole 680B [Suess and von Huene, 1990], where the stratigraphy relies on oxygen isotopes of benthic foraminifera. The radiocarbon age of the top of this layer is 19.6 calibrated kiloyears before the present (19.6 ka B.P.). A reservoir age of 800 years was used throughout the core [Rein et al., 2004]. The program Calib 4.3 [Stuiver and Reimer, 1993] and the decadal atmospheric INTCAL98 calibration data set [Stuiver et al., 1998] were used for calibration. The age model of the core is based on linearly interpolated ages between the calibrated radiocarbon ages. Relying on these interpolated ages, the mean temporal resolution of the color logging sampling was calculated (Figure 4).

\subsection{Chlorins}

[13] Chlorins were determined in $20 \mathrm{~cm}$ intervals according to methods described by Boto and Bunt [1978], Welschmeyer [1994] and Chen et al. [2000]. Eight milliliters of acetone (90\%) were added to $10 \mathrm{mg}$ of homogenized sample powder in two parallel extractions. The samples were ground for $3 \mathrm{~min}$ in an agate ball mill and centrifuged for $15 \mathrm{~min}$. From the resulting clear solution $1.5 \mathrm{~mL}$ were

Table 1. Age Model for 106KL (Part 1)

\begin{tabular}{|c|c|c|c|c|c|}
\hline $\begin{array}{l}\text { Laboratory } \\
\text { Code }^{\mathrm{b}}\end{array}$ & $\begin{array}{l}\text { Sediment } \\
\text { Depth, cm }\end{array}$ & $\begin{array}{l}\text { Conventional, } \\
\text { B.P. } \\
\end{array}$ & $\begin{array}{l}\text { Standard } \\
\text { Deviation }\end{array}$ & $\begin{array}{l}\text { Calibrated Years B.P. After Reservoir } \\
\text { Correction of } 800 \text { Years }(2 \sigma)^{\mathrm{c}}\end{array}$ & $\begin{array}{c}\text { Age Model, } \\
\text { ka B.P. }\end{array}$ \\
\hline KIA 12116 & 809.3 & 11,090 & \pm 50 & $\begin{array}{l}12,740(12,103 ; 11,997 ; 11,981) \\
\quad 11759\end{array}$ & 12.00 \\
\hline KIA 20410 & 893.8 & 12,260 & $+55 /-50$ & $13,804(13,440) 13,120$ & 13.80 \\
\hline KIA 20411 & 956.3 & 13,325 & \pm 50 & $\begin{array}{l}15,560(15,130 ; 14,700 ; 14,400) \\
\quad 14,170\end{array}$ & 14.70 \\
\hline KIA 20412 & 1006.8 & 13,640 & \pm 100 & $15,940(15,480) 14,390$ & 15.48 \\
\hline KIA 20413 & 1038.3 & 14,140 & \pm 70 & $16,510(16,030) 15,210$ & 16.03 \\
\hline KIA 12115 & 1058.8 & 15,180 & \pm 60 & $17,760(17,220) 16,744$ & 17.22 \\
\hline KIA 11814 & 1074.8 & 16,700 & \pm 100 & $19,633(18,976) 18,379$ & 19.63 \\
\hline
\end{tabular}

${ }^{\mathrm{a}}$ Datings of the Holocene $\left(36{ }^{14} \mathrm{C}\right.$ AMS ages and lead and caesium isotopes) were publilshed previously by Rein et al. [2004].

${ }^{b} \mathrm{KIA}$ is Leibnitz Laboratory Kiel (P. M. Grootes).

${ }^{\mathrm{c}}$ Numbers in brackets are the most probable calibrated ages; the numbers left and right of the brackets are minimum and maximum calibrated ages, respectively, within the $2 \sigma$ confidence level. Calibrated ages (calibrated kiloyears before the present (ka) were rounded to 10 years. 
taken (consequently a total of $3 \mathrm{~mL}$ for each sample) and measured with a Turner Fluorometer TD-700. The standard deviation of this method was better than $4.7 \%$.

\subsection{Alkenones}

[14] Paleo-SST estimations have been derived from alkenones $(1 \mathrm{~cm}$ samples at $10 \mathrm{~cm}$ intervals) applying the temperature calibration equation of Prahl et al. [1988]. To extract the alkenones a Dionex Accelerated Solvent Extractor ${ }^{\circledR} 200$ was used. Between 1 and 2 grams of fine grained sediment per sample were extracted at $80^{\circ} \mathrm{C}$ and $1200 \mathrm{psi}$ pressure in three cycles using dichloromethane/methanol $(95: 5 ; \mathrm{v}: \mathrm{v})$ as the eluent. The extracts were dried under a stream of nitrogen and saponified with $0.5 \mathrm{~mL}$ 1-propanolic $\mathrm{KOH}(5 \%)$ for 24 hours at $20^{\circ} \mathrm{C}$ followed by removal of the $\mathrm{KOH}$ and coeluting polar compounds by a solid phase extraction using silica gel columns. These purified extracts were analyzed by GC with a HP-6890 instrument equipped with a HP PTV Inlet on a DB-1 capillary column $(30 \mathrm{~m} \times$ $0.25 \mathrm{~mm}$ i.d.; film thickness $0.25 \mu \mathrm{m}$ ) coupled to a flame ionization detector. The samples were injected splitless in dichloromethane using a cool injection program with solvent venting. The carrier gas was hydrogen at a flow of $0.9 \mathrm{~mL} / \mathrm{min}$. A temperature program of $2 \mathrm{~min}$ isothermal at $56^{\circ} \mathrm{C}, 56^{\circ}-150^{\circ} \mathrm{C}$ at $24^{\circ} \mathrm{C} / \mathrm{min}, 150^{\circ}-320^{\circ} \mathrm{C}$ at $4.7^{\circ} \mathrm{C} / \mathrm{min}$ and $10 \mathrm{~min}$ isothermal was used, giving a good separation of all major compounds. The alkenones were identified by retention times. Quantification was performed relative to external calibration with $\mathrm{n}-\mathrm{C}_{36}$ alkane [Doose-Rolinski et al., 2001]. Precision and accuracy of the alkenone method was checked by repeated measurements $(n=11)$ of control material from a surface sample of the Peru upwelling area. For SST the reproducibility was better than $\pm 0.2^{\circ} \mathrm{C}(\mathrm{p}=0.1)$.

\subsection{Color Logging Data}

[15] Pigment and lithic data were derived from photospectrometric logging with a GretagSpectrolino (GretagMcBeth, Switzerland). With this device, calibrated reflectance spectra (between $380 \mathrm{~nm}$ and $730 \mathrm{~nm}$ wavelength) were measured on the split sediment cores at consecutive $2 \mathrm{~mm}$ intervals. The reflectance spectra display several photosynthetic pigment related absorption bands. Two of these are used in this study. An absorption band minimum at $660-670 \mathrm{~nm}$ wavelength is caused by chlorin absorption. An absorption band minimum centered at $510 \mathrm{~nm}$ wavelength reflects carotenoid (auxiliary photosynthesis pigments) absorption [Rein, 2003]. The depth (intensity) of the absorption bands is a function of the pigment concentration in the sediment. In the same way, the ratio of reflectance between $570\left(\mathrm{R}_{570}\right)$ and $630\left(\mathrm{R}_{630}\right) \mathrm{nm}$ wavelength monitors a characteristic change of the reflectance spectrum continuum. A shift of maximum reflectance is correlated to the lithic concentration in the sediment [Rein and Sirocko, 2002; Rein, 2003; Rein et al., 2004]. Figure 5 shows the down-core variation of the chlorin, carotenoid and lithic matter absorption intensity. A total of 30 replicate analyses on 20 samples (600 analyses) reveal a mean standard deviation of \pm 0.0035 (dimensionless) for the chlorin absorption band, \pm 0.0018 for the carotenoid absorption and \pm 0.002 for the ratio used as a measure for the lithic concentration.
[16] The absorption intensity in the visible part of the electromagnetic spectrum is not a function of the volume (weight) of an absorbing component but of its surface area in a sample. Thus this method already detects small concentrations of fine-grained components (pigments, lithics) but the signal intensity increases nonlinearly with increasing concentration. A nonlinear increase of signal intensity with increasing concentration, especially of fine-grained components, is frequently described for mixtures of solids [e.g., Pieters and Englert, 1993]. Therefore the absorption intensity data derived from the reflectance spectra had to be transformed to approximated concentrations. First, absorption intensity (A) was normalized $\left(\mathrm{A}_{\text {norm }}\right)$ to range between 0 and 1 . For the pigment data, the zero point could be defined by the theoretical continuum over the pigment absorption band [Rein and Sirocko, 2002]. For the lithic data, the zero point is represented by two layers with lowest-ratio $\left(\mathrm{R}_{570} / \mathrm{R}_{630}\right)$ values, from which only nonweighable traces of lithics could be extracted. This concentration was set to zero.

[17] Transfer functions were applied to these normalized intensities. The transfer function (pigment concentration $\approx$ $\mathrm{A}_{\text {norm }}^{2}$ ) for the in situ measured pigment data was found by matching the in situ measured chlorin absorption intensity to the concentration of conventionally measured chlorin data after extraction (see section 3.2). Figure 6a shows the chlorin concentrations derived from both methods. The transfer function to approximate the lithic concentrations (lithic concentration $\approx \mathrm{A}_{\text {norm }}^{1.2}$ ) from the absorption intensity is based on a regression (Figure 7) between the normalized spectral signal and the known lithic concentration in a mixture series. The results of these transformations (Figures $6 a-6 c$ ) are relative concentrations of a component, with a concentration of zero for samples in which the component is not or almost not (lithics) present. A concentration of 1 represents the highest concentration of a component occurring in the core $(0-20 \mathrm{ka})$. The highest lithic concentration found in a $2 \mathrm{~mm}$ thick sample was $92 \mathrm{wt} \%$.

[18] The multiplication of the relative concentrations of a component with the sediment accumulation per time unit (reciprocal value in Figure 4) results in relative flux/accumulation rates (Figures 6d and 6e), expressed as percentage flux of the maximum flux in the record $(0-20 \mathrm{ka})$. The partly stepwise appearance of the flux rate curves depends on the temporal resolution with which accumulation rate changes can be resolved (density of radiocarbon ages). Short-term extreme fluxes or individual events may be suppressed by this method. Thus concentration and flux/ accumulation rates need to be interpreted together.

\subsection{Wavelet Analysis}

[19] Wavelets were calculated with the values of the band ratio $\mathrm{R}_{570} / \mathrm{R}_{630}$ (Figure $5 \mathrm{c}$ ). The wavelet tool described in detail by Torrence and Compo [1998] (available at http:// ion.researchsystems.com/IONScript/wavelet and accessible via the NOAA paleoclimatology webpage) was used to process the data. This tool requires equidistant data that were produced with the Arand Timer module. A maximum of 2000 data points can be processed with the wavelet tool.

[20] Absorption band raw data were resampled to 0.2-year equidistance for the calculation of the wavelets of lithic 


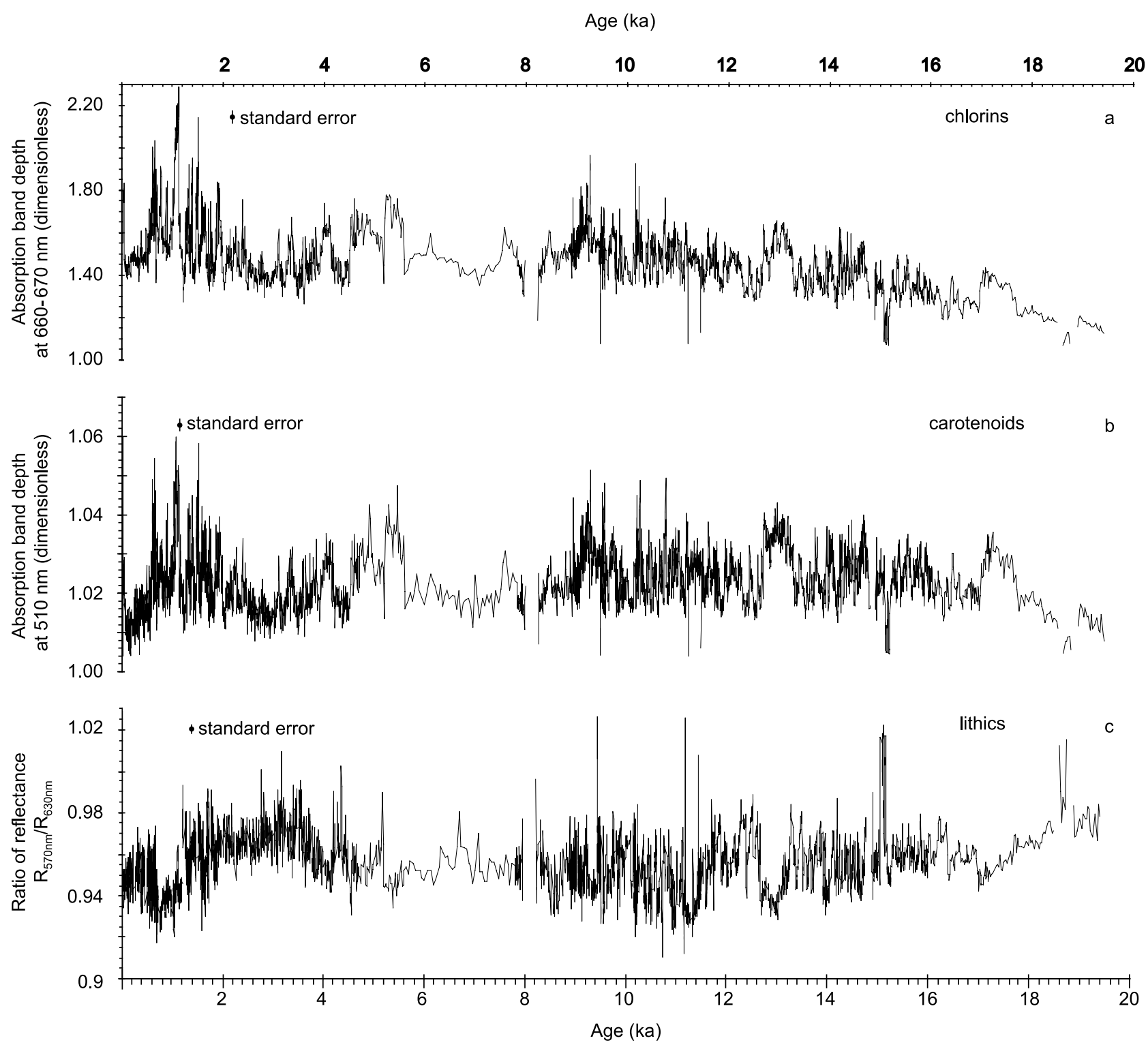

Figure 5. Down-core variability of absorption intensities [Rein and Sirocko, 2002] for (a) chlorin, (b) carotenoid, and (c) lithic matter with standard errors.

variability during the last 2 millennia and the early Holocene. Only values greater than the running centennial mean were considered for wavelet analysis of the decadal variability of the lithic matter during the last 15,000 years. For this analysis, the data series of positive deviations was resampled to 1-year equidistance. Then seven new series were derived from the 15,000 data point series by extracting only every eighth value with each of the seven time series starting one year later. Each of the series was analyzed. Since results are very similar, only one of the wavelets is shown in this study.

\section{Results}

\subsection{Accumulation Rates}

[21] Figure 4 shows the mean temporal sample resolution of photospectrometer logging as number of years repre- sented by the $2 \mathrm{~mm}$ sampling interval. A small number of years indicate high sediment accumulation. The mean sediment accumulation rate was small during MIS2 and during the middle Holocene. Several erosional discontinuities occur during the middle Holocene period between $5.66 \mathrm{ka}$ to $7.81 \mathrm{ka}$ when only $10 \mathrm{~cm}$ of sediment was deposited/preserved (Figure 3). Suess et al. [1987] already observed a sedimentation anomaly in this stratigraphic position. They explained the middle and early Holocene hiatus that they found in all cores on the Peruvian shelf by strong current activity causing erosion. The highest sediment accumulation occurred during the Early Holocene ( 9-10 ka) and during the late Holocene.

\subsection{Photosynthetic Pigment Concentrations}

[22] The marine primary production is strongly reduced during El Niño events. This is long known from observa- 

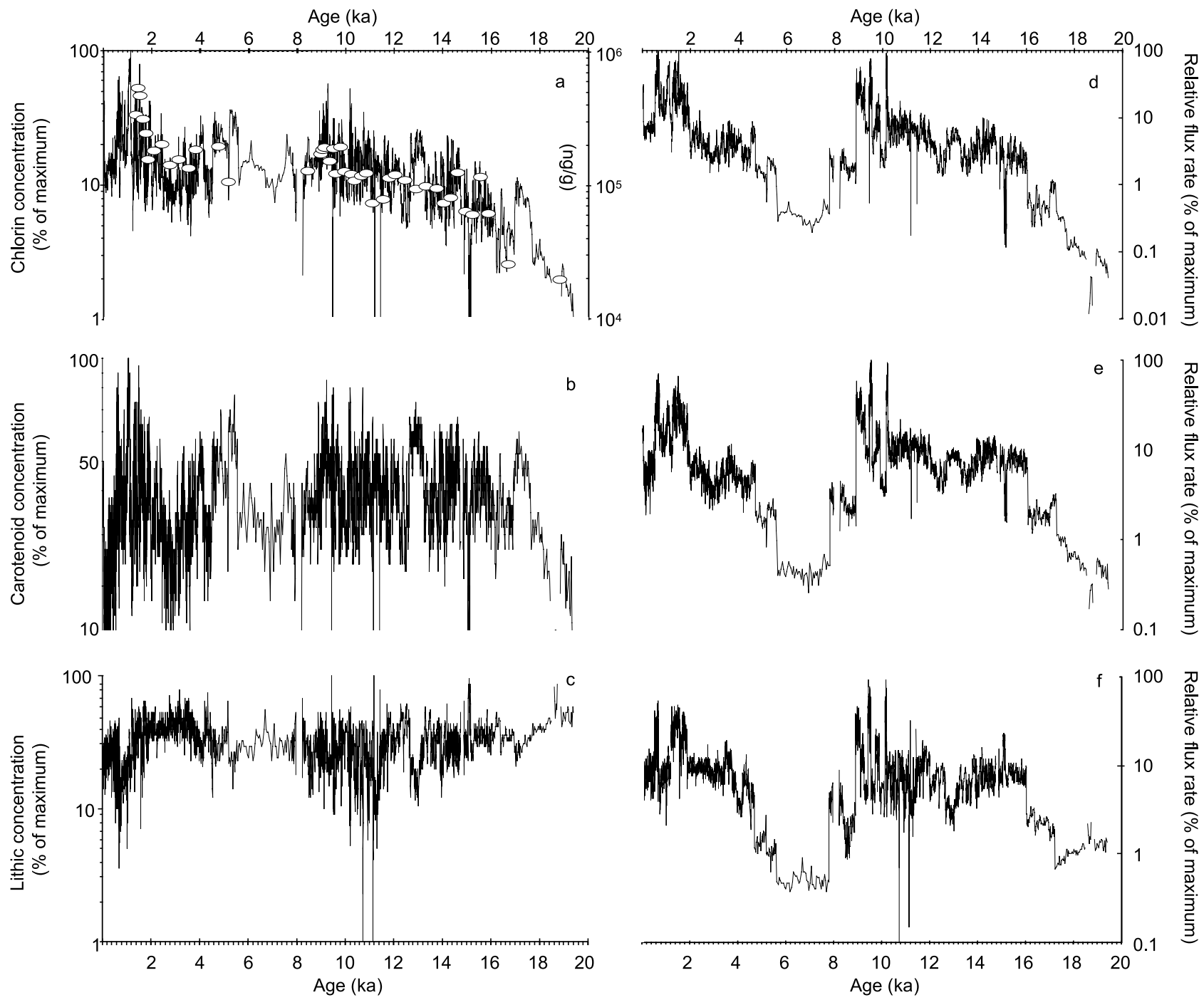

Figure 6. $(a-c)$ Relative concentration and $(d-e)$ relative flux of chlorin (Figures $6 a$ and $6 d$ ), carotenoid (Figures $6 \mathrm{~b}$ and $6 \mathrm{e}$ ), and lithics (Figures $6 \mathrm{c}$ and $6 \mathrm{f}$ ). The white circles in Figure 6a are absolute concentrations of chlorin.

tions made by fishermen and from modern instrumental observations [Arntz and Fahrbach, 1991]. Thus, on interannual timescales pigment concentration minima are expected in sediments that were formed during El Niño events. Actually, the lowest concentrations occur in lithic layers. This appears to be trivial in the first instance since it may be caused by the dilution of one component by the other, but it also reflects the competing conditions/processes that provide both lithic and biogenic components for the sedimentary record. When conditions are favorable for heavy rainfall on the continent (supply of lithics) during El Niño events, the conditions for marine primary production are least favorable since upwelling does not reach into nutrient-rich water below the lowered thermocline. Thus the precipitation (lithics) and the primary production proxy (pigments) are antagonists not only in sensu of dilution but also at the conditions of their origin. Besides interannual variability, considerable changes of pigment concentration

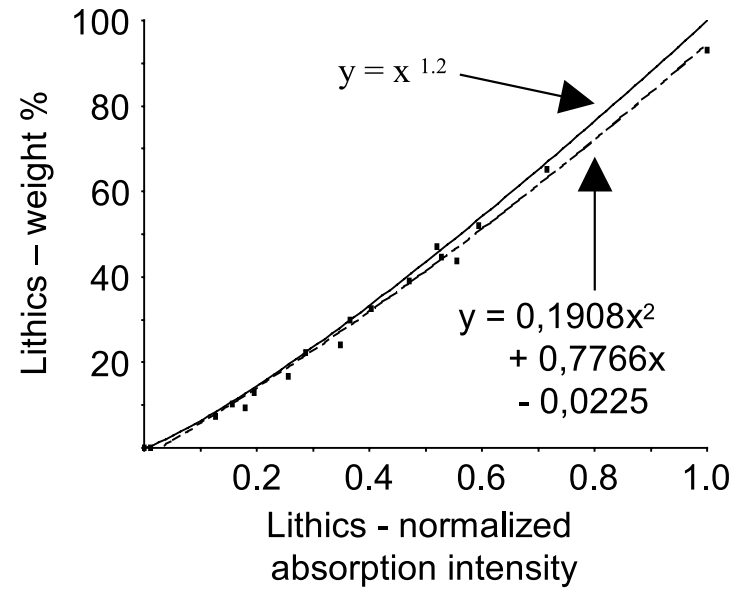

Figure 7. Concentration of lithics-absorption intensity versus weight percent. 
occur on longer timescales (Figures $6 \mathrm{a}$ and $6 \mathrm{~b}$ ). Ignoring extremely low concentrations, the range between the low and maximum chlorin concentrations is 2 orders of magnitude $\left(10^{4}-10^{6} \mathrm{ng} / \mathrm{g}\right)$. Long-term variability may be due to changes in upwelling intensity or the migration of the upwelling cells but can also be caused by altered boundary conditions. Such conditions could be the chemistry of the upwelled water or the nutrient supply from the continent, but also the preservation of the sediment (oxygen minimum zone, bottom currents, burial rate) on the Peruvian shelf [Reimers and Suess, 1983].

[23] Harris et al. [1996] have demonstrated the use of photosynthetic pigments for the estimation of primary production. However, organic matter fractions are prone to sediment diagenesis. The LGM to early Holocene increase of chlorins, organic carbon and the chlorin/carotenoid ratio parallel the sea level rise [Rein, 2003], whereas the more resistant carotenoids used (mainly diatoxanthin and carotene in Peruvian shelf sediments [Repeta and Gagosian, 1984, 1987; Rein, 2003]), do not show this trend [Rein, 2003]. Similarly, a long-term trend in chlorin concentrations over the last glacial cycle since $130 \mathrm{kyr}$ B.P. is observed that is due to the diagenesis of sediment as shown by Rein [2003]. Therefore we prefer the use of carotenoid absorption as a proxy for marine bioproduction.

[24] Chlorin and carotenoid concentrations (Figures 6a and $6 \mathrm{~b}$ ) and relative flux rates (Figures $6 \mathrm{~d}$ and $6 \mathrm{e}$ ) increased distinctly about $17 \mathrm{ka}$ and in a second step by $16.5 \mathrm{ka}$. The highest concentration of pigments occurred during the second millennium before the present, whereas relative flux rates demonstrate that a second pigment and bioproduction maximum occurred during the early Holocene. The middle Holocene flux rates between $8 \mathrm{ka}$ to $5.6 \mathrm{ka}$ are underestimated. They represent minimum estimations because several erosional horizons exist in this interval and the proportion of the eroded sediment is difficult to reconstruct.

\subsection{Lithics}

[25] The lithic concentrations in 106KL are highly variable (Figure 6c). Specifically in two sections, lithic concentrations can be very low. This is after the Younger Dryas until $\sim 10 \mathrm{ka}$ and during a late medieval period (8001250 A.D.). The medieval anomaly has been described and connected to remote anomalies in an earlier paper [Rein et al., 2004]. The medieval period of low El Niño activity [Rein et al., 2004; Mann et al., 2005] is distinguished from the early Holocene period by the observation that lithic concentrations remain on a low level for several hundred years. High and low concentrations, and occasionally even very low lithic concentrations, change with high frequency during the early Holocene. High concentrations of lithics occurred between 4 to $1.3 \mathrm{ka}$, whereas maximum peaks and high-amplitude variability are found during the Late Glacial and early Holocene.

[26] The relative flux rates (Figure 6f) draw a little bit different picture. Lithic accumulation was lowest during the Last Glacial Maximum before $17 \mathrm{ka}$ and during the middle Holocene (8 to $5.6 \mathrm{ka}$ ). Comparable low values are only reached during very short periods during the early Holocene and a short period ( 8.9 to $8.4 \mathrm{ka}$ ) during the transition into the mid-Holocene anomaly. The medieval anomaly is the major anomaly during the late Holocene but less extreme than it appeared to be from the concentration values. Similarly as for the pigments, the transition from a LGM state to a Late Glacial-like and Holocene-like state occurred early, beginning at $17 \mathrm{ka}$ and reaching high fluxes by $16 \mathrm{ka}$. The apparently low variability of flux rates until $10 \mathrm{ka}$, compared to the variability of relative concentrations, is caused by the reduced resolution of the sediment accumulation rate due to less dense radiocarbon dating.

[27] High sediment accumulation rates in combination with low sediment compaction result in a high temporal resolution of proxy data and allow the detection of ENSO frequencies in the late Holocene proxy data (Figure 8). The major variance in the wavelets concentrates in the biennial and ENSO frequency band [Jiang et al., 1995] although differences between the wavelets are observed (time windows). Since down-core sample resolution (depending on sedimentation rate) is not uniform, higher-frequency variability may be cut off in the wavelets when the sedimentation rate is reduced (e.g., Figures $8 \mathrm{c}-8 \mathrm{~d}$ ). The existence or nonexistence of higher frequencies in the wavelets may therefore be strongly influenced by sample resolution.

[28] The deviations of the $\mathrm{R}_{570} / \mathrm{R}_{630}$ ratio from its running centennial means (Figure 9a) were used to minimize the effect of long-term changes in the catchment area. Wavelets were computed with the positive deviation from the centennial mean for the last $15 \mathrm{kyr}$. The wavelet in Figure $9 \mathrm{~b}$ shows significant $(\mathrm{p} \leq 0.1)$ concentration of variance in a 60 to 80 years period. The importance of this period tails off when the positive deviations from the centennial means are small. The 70-year period is thus related to the strongest flood events. A 60 to 80 years period is known from a variety of climate data sets [e.g., Allan, 2000]. The global SST data or precipitation variations in the tropical Sahel region (Africa) are only the most prominent examples. The global SST offers a direct explanation for a 60-80 year periodicity in the El Niño time series.

[29] Flood events were classified as very strong when the lithic concentration was more than 2 sigma above the centennial mean. Figure 10a shows the signal of these events above the 2-sigma level. The number of events that were classified as very strong is shown in Figure $10 \mathrm{~b}$ for nonoverlapping time slices of 500 and 1000 years. An early Holocene maximum occurred between 9 to $10 \mathrm{ka}$ that was only slightly weaker than the late Holocene maximum. Figure $10 \mathrm{~b}$ illustrates that the number of very strong flood events increased during the late Holocene and decreased after $1.5 \mathrm{ka}$. Around $3 \mathrm{ka}$ lithic concentrations are not only very high (Figure 6c), but more extreme events also occurred (Figure 10b).

[30] The Laguna Pallcacocha $\left(2^{\circ} 46^{\prime} \mathrm{S}, 79^{\circ} 14^{\prime} \mathrm{W}\right)$ in the Ecuadorian Andes at $4060 \mathrm{~m}$ above sea level monitors El Niño flood events in the small catchment area [Rodbell et al., 1999; Moy et al., 2002]. From the frequency of flood layers, it is evident that only part of the El Niño events are documented in this lake since the catchment is relatively small and El Niño rainfall is spatially strongly heterogeneous. Contrary to the marine Peru record, the Ecuadorian lake record implies low El Niño activity during the early 
Holocene. The frequency of floods increases toward the late Holocene. A maximum frequency of flood events occurred at around $5 \mathrm{ka}$ contemporaneous with lithic maxima in ocean sediments off Peru. The flood frequency was also high during the last 2 millennia, though it declined after

Wavelet power spectrum (normalized to global)

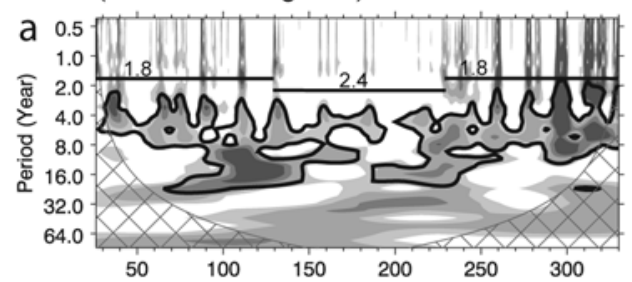

Global wavelet
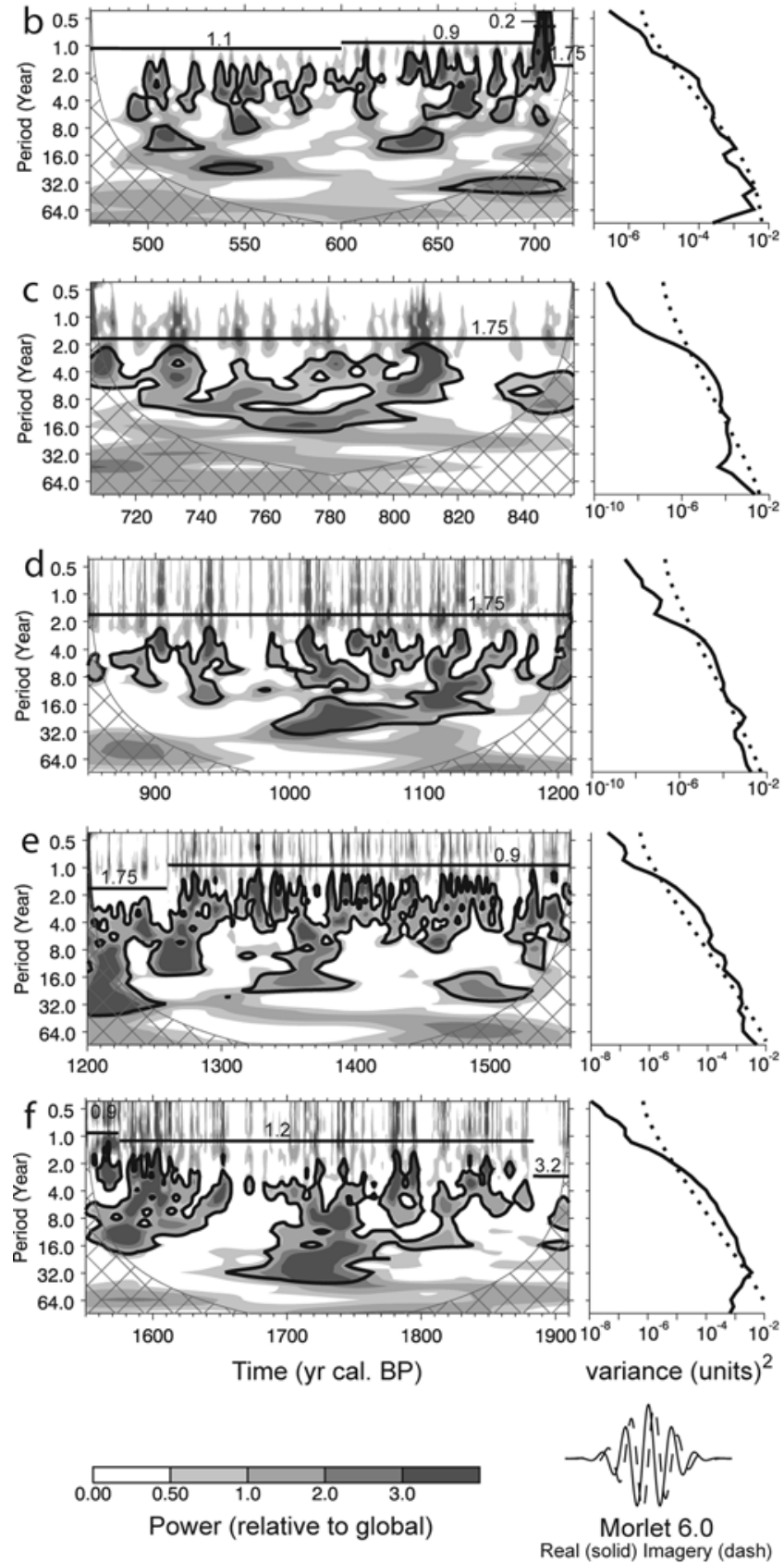

$1.2 \mathrm{ka}$ (A.D. 750). A minimum of events occurred during the medieval period when the Peru record indicates persistently low El Niño activity [Rein et al., 2004]. The major difference between both records is during the early Holocene. Deduced from the frequency and amplitude of the lithic peaks (Figures $6 \mathrm{c}$ and $10 \mathrm{~b}$ ) occurring in 106KL, it is evident that the early Holocene was a period of strong flood activity in Peru.

\subsection{Sea Surface Temperature}

[31] The modern sea surface off Peru shows seasonal and interannual variability. Monthly long-term means in the study area are between $15^{\circ} \mathrm{C}$ and $22^{\circ} \mathrm{C}$ with the cooler temperatures occurring during May to October/November and higher temperatures from January to April (monthly sea surface temperature maps are available on the website of the İnstituto del Mar del Peru (http://200.60.133.147/uprsig/ sst prov.html)). The annual mean is about $18^{\circ} \mathrm{C}$. The cool Peru-Chile current and especially the upwelling of cool water from the deep are responsible for the cold sea surface temperature that is observed along the South American west coast. The surface water temperature is normally $5^{\circ}-7^{\circ} \mathrm{C}$ cooler along the coast than $1000 \mathrm{~km}$ off the coast at $12^{\circ} \mathrm{S}$ (SST maps provided by the Instituto del Mar del Peru).

[32] The alkenone record from which our sea surface temperature estimations were derived ends in the 1960s. The estimated temperature for the uppermost sample is $21.3^{\circ} \mathrm{C}$. This is the coolest reconstructed SST over the last 500 years (range 21.3 to $21.9^{\circ} \mathrm{C}$, Figure $11 \mathrm{c}$ ) and also a rather cool temperature compared to most of the Holocene and Late Glacial samples. However, it is in the upper range of modern SST variation. This is not surprising as the coccolithophoridae (synthesizing the long-chain alkenones) preferentially grow during the months with warmer SST and less nutrient availability. Coccolithophoridae reach their maximum abundance during the El Niño warm water anomalies when surface water is depleted in nutrients. Thus the alkenone thermometer is preferentially a recorder of warm water conditions.

[33] Off Peru, SST was about $18.6^{\circ} \mathrm{C}$ during the Last Glacial Maximum at $19 \mathrm{ka}$ (Figure 11c). The sea surface warmed to $\sim 21^{\circ} \mathrm{C}$ until $17 \mathrm{ka}$ and warming continued to almost $23^{\circ} \mathrm{C}$ by $16.5 \mathrm{ka}$. A period with cool SST is prominent between $12.8 \mathrm{ka}$ to $11.9 \mathrm{ka}$ (Figure 11c) and closely matches the Younger Dryas event that is dated to $12.8-11.6 \mathrm{ka}$ in the GISP2 ice core [Grootes et al., 1993]. During the late Holocene after 5.6 ka, the SST off Peru is

Figure 8. Wavelet power spectra and global wavelets for lithic concentrations. The power of the wavelet has been scaled by the global wavelet spectrum. The cross-hatched region is the cone of influence, where zero padding has reduced the variance. Black contour is the $10 \%$ significance level, using a red noise (autoregressive lag 1) background spectrum. The numbers above the horizontal black lines in the wavelets show the original sample resolution before resampling. The dashed line in the global wavelet is the significance for the global wavelet spectrum, assuming the same significance level and background spectrum as for the wavelet power spectrum. 

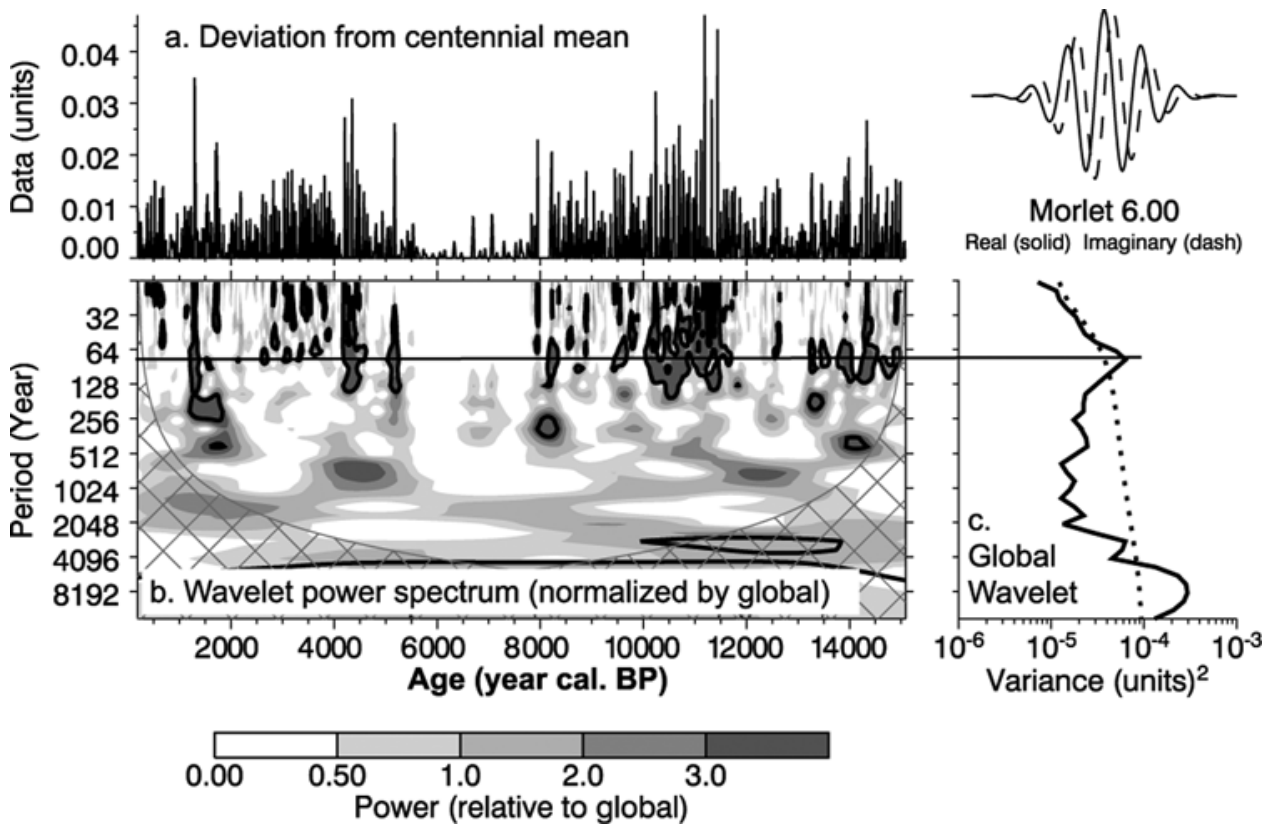

Figure 9. (a) Occurrence of lithic concentration above the running centennial means, (b) wavelet power spectrum, and (c) global wavelet for lithic concentrations larger than the centennial mean. The power of wavelet has been scaled by the global wavelet spectrum. The cross-hatched region is the cone of influence, where zero padding has reduced the variance. Black contour is the $10 \%$ significance level, using a red noise (autoregressive lag 1) background spectrum. The dashed line in the global wavelet is the significance for the global wavelet spectrum, assuming the same significance level and background spectrum as for the wavelet power spectrum.

much more variable compared to the early Holocene variability. The SST record is characterized by large millennial-scale changes with relative temperature minima centered at $3 \mathrm{ka}$ and during the last centuries. The $3 \mathrm{ka}$ cooler period is apparently a basin-wide climatic cooling [McGlone et al., 1992] that does not necessarily reflect local changes in the occurrence of warm water anomalies. The warmest SST of the last 20,000 years, with maximum SST beyond $23^{\circ} \mathrm{C}$, occurred during the second millennium before the present.

\section{Discussion}

\subsection{LGM and Major Changes $18-16 \mathrm{ka}$}

[34] A LGM temperature $\sim 3^{\circ} \mathrm{C}$ below the modern level is concordant with SST changes observed in the EEP and Western Equatorial Pacific (WEP). After the LGM the sea off Peru warmed up rapidly and reached temperatures comparable to cool Holocene-like temperatures already by $18-17 \mathrm{ka}$. The first SST maximum was reached at $\sim 16.5 \mathrm{ka}$ with temperatures comparable to warm Holocene temperature levels and $1.5^{\circ} \mathrm{C}$ above SST in the top of the core (1960 A.D.). This early warming also appears in a record near the Galapagos Islands (Figure 2, V21-30). However, the LGM cooling at this site in the center of the East Pacific cold water tongue is weaker, only $\sim 1^{\circ} \mathrm{C}$ [Koutavas and Lynch-Stieglitz, 2003]. In contrast, LGM sea surface temperatures in EEP core TR163-19 [Lea, 2004] and in West Pacific Warm Pool core ODP806B [Lea et al., 2000] increased only gradually, reaching Holocene-like SST levels
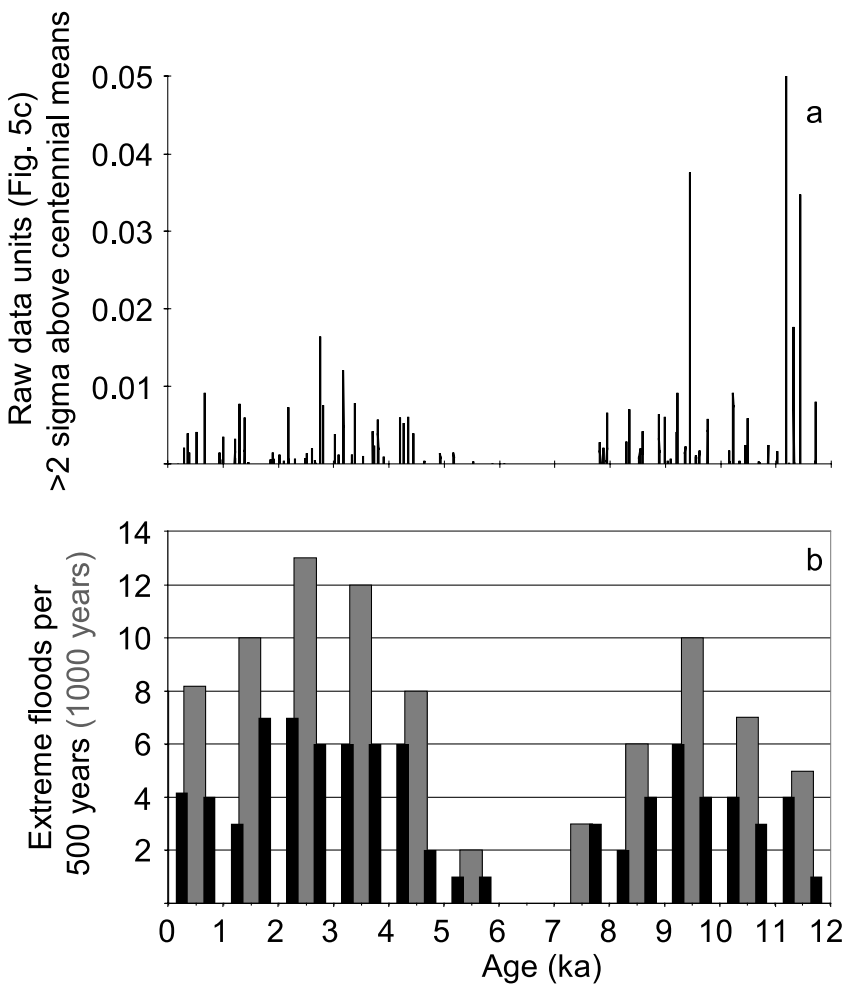

Figure 10. (a) Strong flood events with signal intensities beyond 2 sigma above the running centennial means. (b) Frequency of these very strong El Niño flood events per 500 (black bars) and 1000 (grey bars) years. 

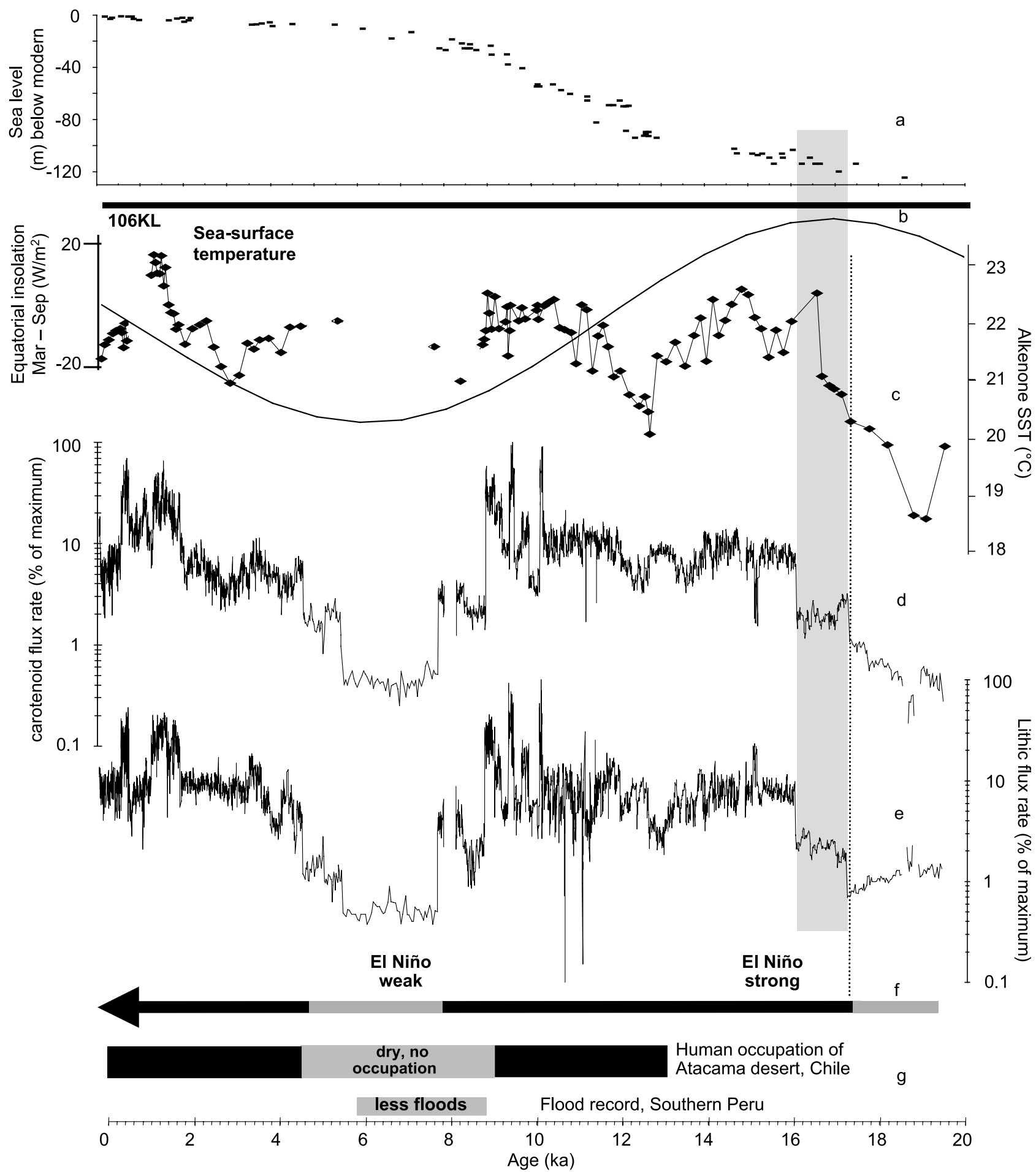

Figure 11. Proxies since the Last Glacial Maximum. (a) Sea level change [Fairbanks, 1992]. (b) Mean sample resolution in years of carotenoid and lithic sampling between radiocarbon ages. (c) March minus September insolation [Berger, 1978]. (d) Sea surface temperature. (e) Carotenoid and (f) lithic down-core variation. (g) Mid-Holocene precipitation anomalies from other records [Fontugne et al., 1999; Keefer et al., 1998; Núñez et al., 2002]. The dashed vertical line marks the suggested onset of ENSO, contemporaneous with the North Atlantic Heinrich event 1 (grey vertical bar). 
not before the Holocene period (TR163-19, ODP806B) or during the LG Boelling/Alleroed equivalent in the Sulu Sea [Rosenthal et al., 2003]. The timing of the early deglaciation SST increase (off Peru) is similar to that observed in the Southern Ocean [Imbrie et al., 1992; Pahnke et al., 2003; Lamy et al. 2004] and is thought to reflect the Antarctic thermal signal. This could explain why the Galapagos record located below the Equatorial Undercurrent shows a similar early warming to that off Peru. However, the 106KL SST record is distinguished from Southern Hemisphere archives by the SST increase to Holocene-like temperature levels as early as $17 \mathrm{ka}$. Thus additional process(es) is (are) required to explain the early warm SST off Peru.

[35] Major changes occurred in Peru between 18 and $16 \mathrm{ka}$ when ENSO proxies (sedimentation rate, lithics, pigments (Figures 4, 6, and 11) increased strongly. Contemporaneously, SST (Figure 11c) jumped between 17 and $16 \mathrm{ka}$ to a level, comparable to or even exceeding Holocene temperatures. Pigments (Figures 6a, 6b, and 11d) increased parallel to the onset of warming (possibly because of changed water chemistry, for glacial-interglacial changes see [Beaufort et al., 2001; Loubere, 2000, 2002]) of the ocean immediately prior to the increase of lithic compounds. The increase of pigment concentrations (Figures 6a and 6b) was several hundred years ahead of the increase of lithic concentrations (Figure 6c). This indicates that (1) fertilization by terrigeneous matter was not of importance for the increased primary production, and (2) changed bottom current activity cannot be the reason for the increasing deposition of lithics since then the denser lithic compounds should lead. At that time, land-sea areal changes (Figure 1) were rather small around the study site since sea level (Figure 11a) was still near its LGM lowstand [Fairbanks, 1992; Siddall et al., 2003]. Thus an increased lithic flux cannot be the result of changed dispersal patterns of continental detrital matter during elevated sea level and less direct export down to the deep sea trench. The $>63 \mu \mathrm{m}$ fraction which is mostly composed of fecal pellets decreases to only $2-4 \%$ of the sediment after $18 \mathrm{ka}$ [Wolf et al., 2001]. This implies that the deposition of resuspended coastal sediments due to sea level transgression was not the cause for the major changes between 18-16 $\mathrm{ka}$ and also had little influence on the later record because of the sheltered position of site 106KL behind a landward ridge (Figure 1). We assume the increasing lithic amounts reflect increased precipitation on the continent, thus marking the onset of stronger El Niño activity in Peru [Rein, 2003]. Comparable early El Niño activity $17-13 \mathrm{ka}$ is also suggested by Rittenour et al. [2000] as they found ENSO-like frequencies in North American varved lake sediments. Similarly, Skilbeck et al. [2004] found El Niño frequencies in a high-resolution section of a core from the Peru margin starting at $17.2 \mathrm{ka}$.

[36] Thus, in Peru, stronger El Niño activity did not start before the maximum of equatorial seasonality (Figure 11b) that is indexed by the March minus September insolation. This index represents the orbital forcing in the Zebiak and Cane [1987] model that is used for El Niño prediction. The onset of stronger El Niño activity did not occur during the LGM as predicted by the orbitally driven Zebiak and Cane model (with modern boundary conditions) but $2-3 \mathrm{kyr}$ later.

[37] The onset of stronger El Niño activity coincides with the destruction of Laurentide Ice Sheet during Heinrich event 1 (grey bar in Figure 11). If enhanced El Niño activity preceded the Heinrich event, this could have contributed to the destabilization of the Laurentide ice sheet. Kukla et al. [2002] suggest that (modeled) stronger El Niño activity would have started the buildup of ice sheets by transferring the surplus tropical moisture toward the higher latitudes at the end of the last interglacial. Moisture from stronger El Niño activity could then have been one source that forced the critical snow accumulation and subsequent mechanical self-destruction of Laurentide ice sheet [MacAyeal, 1993].

[38] If Heinrich event 1 preceded the onset of stronger El Niño activity off Peru it could have triggered the sudden start of El Niño activity. Adams et al. [2003] found proxy evidence for an El Niño-like response to volcanically forced cooling (over the last centuries). Climatic cooling caused by Heinrich event 1 may have had a similar effect causing an El Niño-like response of the dynamical Pacific Ocean thermostat [Clement et al., 1996]. These scenarios must remain speculative as long as the lead and lag between El Niño onset and Laurentide ice surge cannot be resolved because of dating uncertainties. However, the apparently sudden increase of El Niño activity more or less contemporaneously with the beginning destruction of the Laurentide ice sheet needs further investigation.

\subsection{Late Glacial}

[39] During the early Late Glacial (15-13.8 ka) SST varied by $\sim 1^{\circ} \mathrm{C}$ (Figure 11c). From its (second) temperature maximum at $15 \mathrm{ka}$, temperature declined with several large fluctuations during the Boelling/Alleroed complex into the Younger Dryas (YD, 12.9 to $11.8 \mathrm{ka}$ in 106KL age model). Koutavas et al. [2002] proposed weaker El Niño activity for the time of the Boelling warming. In the 106KL data there is evidence for that but we cannot find a general shift in sediment properties: The gradually declining SST off Peru could reflect less intense or less frequent warm water anomalies. The minima of lithic concentrations and also of lithic flux are slightly lowered but the amplitudes are distinctly increased. Only two short periods $(14.2-14 \mathrm{ka}$, $13-12.6 \mathrm{ka})$ can be identified when significantly less and weaker El Niño events (lithics) occurred.

[40] During the Younger Dryas the sea surface cooled rapidly but kept $1.5^{\circ}-2^{\circ} \mathrm{C}$ warmer than the LGM minimum temperatures (Figure 11c). A persistent pigment maximum (Figures 6a, 6b, and 11d) and a lithic minimum (Figures 6c and 11e) occurred at the beginning of the YD. After $12.6 \mathrm{ka}$ the pigment concentrations collapsed and lithic input increased at site 106KL. At the beginning of the YD period, the strongly increased bioproductivity and reduced SST support a strongly enhanced nutrient flux and weak El Niños that are followed by stronger El Niño activity during the later YD. This is in accordance with prevailing dry conditions (anticorrelated to the Peru El Niño region) in the Sulu Sea [Oppo et al., 2003] and in the Cariaco Basin [Peterson et al., 2000]. However, these studies found no indications for weaker or less frequent El Niño conditions 
(wetter than normal) at the beginning of the Younger Dryas. Both sites are not in the core of the ENSO region and are primarily part of other circulation systems. Thus our results from the Peru ENSO region support the modeling results of Clement et al. [2001] who suggest an extended period with reduced El Niño activity at the beginning of the Younger Dryas event [Clement et al., 2001].

\subsection{Early Holocene}

[41] The SST started to rise at the end of YD with large fluctuations until $10.3 \mathrm{ka}$. Two dry periods occur (11.5$11.25 \mathrm{ka}, 11.05-10.95 \mathrm{ka}$ ), of which the first was in parts even drier than the early YD, but less persistent. During this time of transition the periods of weaker and stronger $\mathrm{El}$ Niño activity (Figures 5c, 6c, and 11e) alternated on a centennial scale with increasingly stronger El Niño activity.

[42] Between 10.3 and $8.9 \mathrm{ka}$ the SST off the coast of Peru was rather invariant, about $2^{\circ} \mathrm{C}$ warmer than today, and warmer than during most of the Holocene. It is not clear whether this temperature optimum in Peru is only a reflection of the widely observed early Holocene thermal optimum [e.g., Haug et al., 2001; Emeis and Dawson, 2003] or if it is at least in part a result of intense warm water anomalies off Peru. Marine bioproductivity and continental runoff were highly variable in Peru at that time. Four early Holocene intervals $(9.28-8.9 \mathrm{ka}, 9.56-9.44 \mathrm{ka}$, 9.9-9.74 ka, and $10.21-10.15 \mathrm{ka}$ ) display sedimentation rates which allow subannual or slightly lower sample resolutions (Figure 4). A major and highly significant concentration of variance above the $90 \%$ confidence level occurs at the biennial and ENSO frequency band $(2-8 \mathrm{a}$ [Jiang et al., 1995]) in each of the analyzed time windows [Rein, 2003]. Strong lithic peaks recurring with ENSO frequencies indicate that strong El Niño floods were abundant during the early Holocene.

\subsection{Middle Holocene (8-5.6 ka)}

[43] During the middle Holocene Niño3 model temperature anomalies [Clement et al., 1999] and the seasonality index (Figure 11b) indicate reduced El Niño activity because of less favorable seasonal heating at the equator. Cooler SST's near Galapagos are also interpreted as being caused by reduced El Niño activity during the midHolocene [Koutavas et al., 2002]. Concordant, continental evidence for extremely dry conditions and a lack of large river flood deposits are reported from Peru [Keefer et al., 1998; Fontugne et al., 1999]. Furthermore, there is a gap in the human occupation of the Atacama Desert in northern Chile during this period [Núñez et al., 2002] (Figure 11g). As weak El Niño activity requires, a wetter climate is reported in the Austral-Asian region [McGlone et al., 1992; Shulmeister and Lees, 1995; Shulmeister, 1999].

[44] If we assume weak El Niño activity, we should expect extensive marine primary production and reduced lithic input because of drier regional climate on the Peruvian shelf. However, the period $8.8 \mathrm{ka}$ to $5.6 \mathrm{ka}$ appears not to be a period of high organic matter concentration (Figures 6a and $6 \mathrm{~b})$. This is probably due to the observation that the middle Holocene between $8.8 \mathrm{ka}$ and $5.6 \mathrm{ka}$ is not well preserved in core $106 \mathrm{KL}$ nor in all other sediment cores recovered on the Peru margin [Suess et al., 1987]. The flux rates were very low during the middle of the Holocene (Figure 9) although, as stated earlier, flux rates may be underestimated because of eroded sediment. However, flux rates were probably not above the level that they were after $5.6 \mathrm{ka}$. Less favorable preservation conditions for organic matter [Reimers and Suess, 1983] with the reduction of lithic input (burial of organic matter) and consequent recycling of organic matter could explain the low organic matter concentration and accumulation (Figures 6a and 6b). Another explanation could be that upwelling was not enhanced during the middle of the Holocene period; this is less probable because SST in the equatorial upwelling region dropped [Koutavas et al., 2002]. Several researchers [Sandweiss et al., 2001; Andrus et al., 2002] found indications for warmer SSTs and reduced trophic levels together with dry conditions on the continent, though the habitat of mollusc and fish remains used for these SST reconstructions have been questioned [DeVries et al., 1997; Wells and Noller, 1997]. With regard to erosional features in cores from the Peruvian shelf, oceanographic conditions along the Peruvian coast were extreme and apparently different from those during the rest of the time slice presented in this study.

\subsection{Late Holocene (After 5.6 ka)}

[45] Beginning at $5.6 \mathrm{ka}$, the sediment flux rates recovered from their minimum during the middle Holocene (Figures 11d and 11e). The change between $6 \mathrm{ka}$ to $5 \mathrm{ka}$ coincides with previously reported major climatic changes around the equatorial Pacific. The water level of Lake Titicaca recovered from its lowest level of the last 25,000 years which was reached between 6-5 ka within a dry period since $9 \mathrm{ka}$ [Baker et al., 2001]. In northern Peru a heavily debated period of relatively warm coastal waters ended [Sandweiss et al., 1996, 1997; DeVries et al., 1997; Wells and Noller, 1997; Sandweiss et al., 2001; Andrus et al., 2002]. In an Ecuador lake, sediments with rainstorm-induced layering start to reflect El Niño pacing at $5 \mathrm{ka}$ [Rodbell et al., 1999; Moy et al., 2002]. In the AustralAsian region interannual climate variability increased $5 \mathrm{kyr}$ B.P. (uncalibrated years before the present) and became dominant after 3 kyr B.P. [McGlone et al., 1992]. Coral series from the western Pacific strongly exhibit ENSO-like periodicities [Corrège et al., 2000; Tudhope et al., 2001]. Concordant with those climatic changes we ascribe the enhanced lithic input (Figure 11e) onto the Peruvian shelf to the reinforcement of El Niño activity after $5.6 \mathrm{ka}$ to $5.2 \mathrm{ka}$.

[46] Sandweiss et al. [2001] stressed a maximum of El Niño activity after 2.8 ka that possibly caused the abandonment of monumental temples in Peru which had been built since $5.8 \mathrm{ka}$. They report that the latest of the archeological sites (Manchay Bajo) that was occupied until $2.8 \mathrm{ka}$ is the only site that was protected by walls against river flooding. The walls were built after $3.4 \mathrm{ka}$ [Sandweiss et al., 2001], about the time when some thicker lithic layers were deposited at site 106KL (Figures 5c and 6c). These thicker individual events appear much smaller in the lithic flux rates (Figures $6 \mathrm{f}$ and 11e) because extreme events are smoothed by mean sediment accumulation.

[47] Tudhope et al. [2001] found similar or slightly lower than modern El Niño strength between 3 and $2 \mathrm{ka}$. They 
present no data for the second millennium B.P. when the Peru proxy data show maximum El Niño strength, with strong individual events (lithic concentration) and a generally high lithic flux and highest SST on record. On the other hand, we have no modern benchmark for the 106KL record, since the undisturbed $106 \mathrm{KL}$ proxy data record available for color logging ends in the 1920s [Rein et al., 2004]. We only have supporting evidence from other cores that El Niños were distinctly stronger than modern events between 2$1.3 \mathrm{ka}$. Core SO147-4SL (Figure 1) covers the Holocene and is situated between core location $106 \mathrm{KL}$ and the coastline. The youngest sediments in this core reach into the last millennium [Wolf, 2003] and contain several $\mathrm{cm}$ thick clayey silt flood layers [Dullo et al., 2000] (a core photograph is presented in the supplements to the Rein et al. [2004] work). The thickness of these flood layers has no counterpart in the rest of this core, nor in short cores from the close vicinity of 4SL that contain the sediment surface. This shows that none of the modern or prerecent events can compare in strength with these events of the second millennium before the present.

[48] In contrast to the maximum El Niño activity in the second (Figure 11e) and third (Figure 6c) millennium B.P., El Niños were persistently weak between 800 and 1250 A.D. (late medieval period). This major Holocene El Niño anomaly and its teleconnections in the Indo-Pacific domain and into the Cariaco Basin are described by Rein [2003] and Rein et al. [2004]. Coral proxy evidence for significantly lower than normal El Niño activity during the late medieval period has also been found by Cobb et al. [2003]. The causes for the late medieval ENSO anomaly are unknown.

\subsection{The Last Millennium}

[49] The last millennium starts within the aforementioned period of low El Niño activity. After the medieval anomaly, since A.D. 1250, lithic concentrations were average for the Holocene, with gradually decreasing amplitudes of lithic concentrations. However, sediment flux regained preanomaly values for a short period $(0.7-$ $0.5 \mathrm{ka})$ after the medieval anomaly. The radiocarbon ages at $0.7 \mathrm{ka}$ and $0.5 \mathrm{ka}$, where the flux rate changes dramatically, were set on lithological boundaries. Thus the stratigraphic position of the flux rate change is real and not an artifact of dating. The sediments of the last five hundred years are rather uniform with only microscopically recognizable lamination. No indication for a further dramatic change of flux rate could be found. Consequently, concentrations of different stratigraphic levels can be compared keeping in mind the changes at $0.7 \mathrm{ka}$ and $0.5 \mathrm{ka}$. Concentration values are preferred since individual events may be suppressed in the coarser resolution of flux rates (see above).

[50] To test the significance of our lithic proxy for El Niño strength off Peru in a wider context, the lithic El Niño flood proxy (concentrations) is compared with temperature reconstructions [Mann et al., 1999; Mann and Jones, 2003; Esper et al., 2002] that are available for the last millennium (Figure 12). These temperature reconstructions provide perspective for the recent evaluations on global climatic change [Crowley, 2000]. Of special interest is whether there was a preindustrial late medieval temperature optimum with temperatures comparable to those during the 20th century but accompanied by distinctly lower atmospheric $\mathrm{CO}_{2}$ concentrations. Reconstructions of summer temperatures (tree ring data) and for regions north of $30^{\circ} \mathrm{N}$ [Crowley and Lowery, 2000; Briffa et al., 2001; Jones et al., 2001; Esper et al., 2002] show a medieval thermal optimum. In contrast, a global reconstruction based on multiproxy data [Mann et al., 1999; Mann and Jones, 2003] that include tropical and Southern Hemispheric (SH) archives (including those of the Northern Hemisphere (NH) reconstructions) as well as more annual (year-around) temperature information, display a rather homogeneous preindustrial temperature. The global Mann and Jones [2003] data set shows slightly warmer $\mathrm{NH}$ temperatures during the medieval period ( $~ 800-1400$ A.D.) but not in the SH although the database there is less dense. Thus the NH thermal optimum might be a peculiarity of the summer season in the higher northern latitudes.

[51] Since our age model relies on radiometric dating, uncertainties and dating errors arise from (1) assumptions made on the reservoir ages, (2) the laboratory dating error (3), the calibration process and (4) the linearly interpolated ages between the radiometric dates. Despite these uncertainties, age discrepancies between our record and the continuously dated (tree ring and annual ice layer) paleotemperature records are very small. However, a slight tuning of our time axis to the global temperature reconstruction [Mann et al., 1999] has been carried out (Figure 12). The magnitude of these corrections is smaller than the errors associated with our radiocarbon timescale. The highest lithic maximum of the last millennium during the 13th century is probably due to a catastrophic flood event, the epic flood, called Miraflores flood in the southern and Nyamlaps flood in the northern part of Peru [Kosok, 1965]. This flood event was apparently followed by another strong flood event. These flood events were tuned (adjustment is 17 years) to the highest temperature peak in the global temperature curve [Mann et al., 1999]. The youngest radiocarbon age was corrected by 2 years. Corrections of our timescale are indicated in Figure 12 together with the size of the adjustment. These adjustments are due to slightly changing sedimentation rates, which are not considered in the linear interpolation between radiocarbon ages. A more detailed tuning was not considered since it would be hypothetical and does not influence the points made here.

[52] The points are that decadal to multidecadal minima of El Niño activity resemble temperature minima in the global and partly in the Northern Hemisphere temperatures after the late medieval period of persistently weak El Niños. Secular variations are also largely positively correlated: On average, temperature reconstructions show higher temperatures with increased El Niño activity and lower temperature with reduced El Niño activity. However, there are prominent exceptions from these observations when climate (temperature) was more extreme: (1) In the late 13 th and the early 17 th century temperatures in the Northern Hemisphere were rather cool but El Niño activity was high [see also Cobb et al., 2003]. (2) In the 19th 

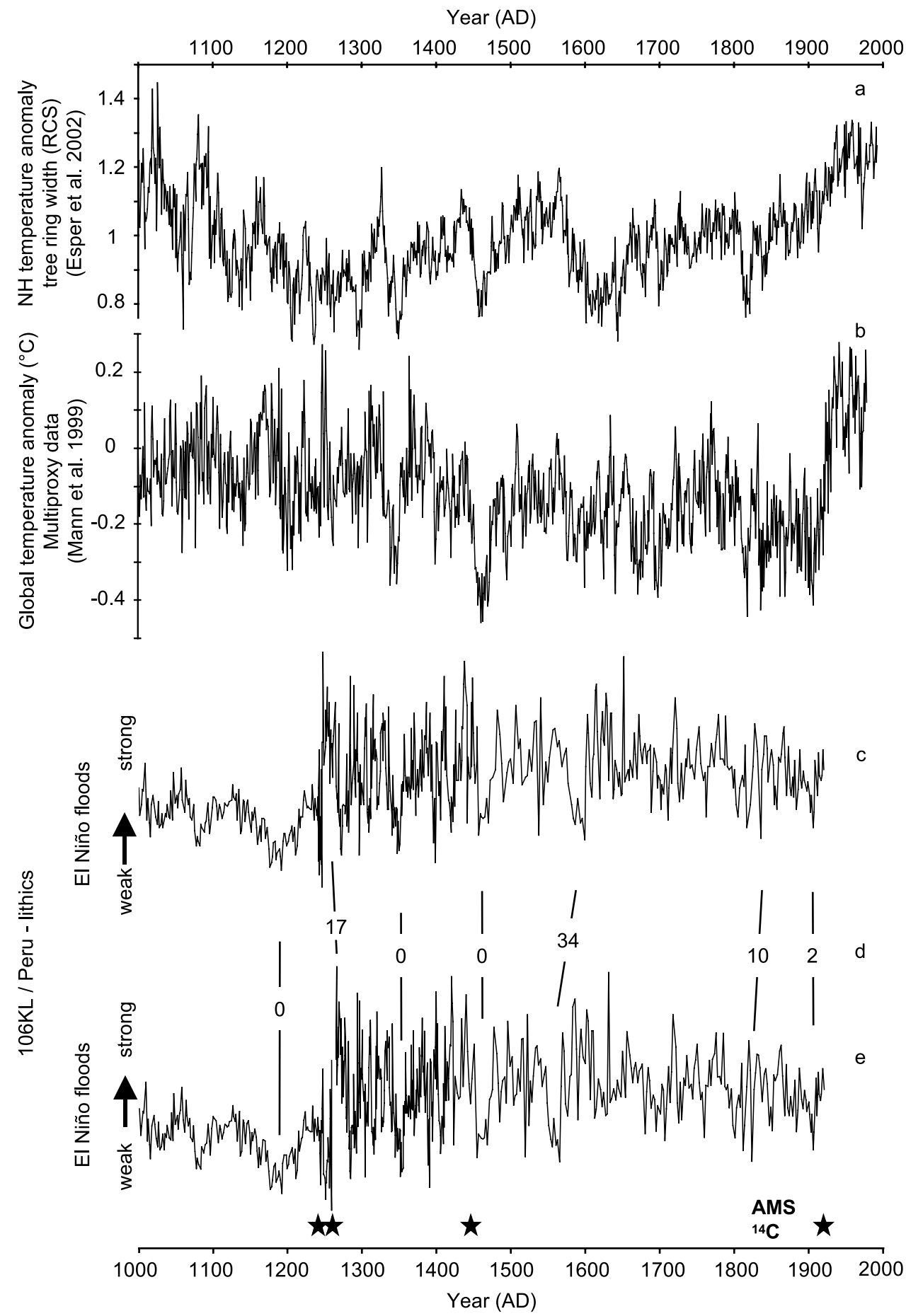

Figure 12. Comparison of 106KL El Niño flood record (lithic concentration) with temperature reconstructions from (a) Esper et al. [2002] and (b) Mann et al. [1999] and (c) tuned 106KL time series with (d) size of timescale adjustment applied to the untuned (e) radiocarbon dated 106KL time series.

century $\mathrm{NH}$ temperature was increasingly warmer but El Niño activity and global temperature were decreasing. (3) Within the medieval period of extraordinarily weak El Niño activity $\mathrm{NH}$ temperatures peaked; the period as a whole and secular temperature and El Niño activity variations are anticorrelated. Dating uncertainties could easily be held responsible for the secular anticorrelation within the medieval anomaly but even so, that would leave a broad medieval El Niño weakening during the $\mathrm{NH}$ medieval thermal optimum.

[53] These exceptions seem to reflect basic principles described by Bjerknes [1969]. Stronger trade winds in response to a warming of the western Pacific result in a cooling (upwelling) of the eastern Pacific and weaker El 
Niño activity. Clement et al. [1996] described this as an "ocean thermostat" mechanism. Similarly, Adams et al. [2003] showed that the probability of El Niño events was doubled after strong volcanic eruptions (cooling) in the tropics. Proxy data [Verschuren et al., 2000; Jones et al., 2001; Hendy et al., 2002; Cobb et al., 2003; Mann et al., 2005] support an El Niño-like response to cooling [Mann et al., 2005].

[54] Alternatively, a partly positive correlation between temperature and El Niño activity might be supported by findings of Kukla et al. [2002], which illustrate that zonal seasonal air and sea surface temperature anomalies (since A.D. 1950) are correlated to the state of ENSO, with higher tropical and global temperatures during mean El Niño events. During boreal spring (April to June) the globe, with exception of regions between $60^{\circ} \mathrm{S}$ and $70^{\circ} \mathrm{S}$, is warmer than normal (tropics warm much more strongly), whereas portions of the higher latitudes $\left(60^{\circ} \mathrm{N}\right.$ to $75^{\circ} \mathrm{N}$ and $30^{\circ} \mathrm{S}$ to $75^{\circ} \mathrm{S}$ ) are cooler than normal during boreal autumn [Kukla et al., 2002].

[55] We conclude that the relations observed reflect at least two cases: During some periods El Niño activity largely contributes to the temperature signal (positive correlation), while during others an external forcing from the strongly cooled or warmed higher latitudes is imposed on the tropical ENSO resulting in an anticorrelation ("dynamic Pacific ocean thermostat"').

[56] However, the ENSO teleconnection pattern may have changed in the past. The anomalous weakness of El Niño events during the medieval period must have cooled the mean climate of at least large parts of the tropics. This could be the reason why the tropical medieval warming is much weaker than in the higher northern latitudes.

\section{Conclusions}

[57] In this study, we presented new, very high resolution proxy data for El Niño activity in Peru since the Last Glacial
Maximum. The high temporal resolution of the data could be accomplished using nondestructive methods of in situ reflectance spectroscopy at $2 \mathrm{~mm}$ sampling intervals. Material specific absorption features in reflectance spectra were exploited to derive lithic matter and photosynthetic pigment concentrations in the core. A dense grid of radiocarbon ages allowed the estimation of flux rates. The high-resolution proxy data are supported by decadal to multidecadal resolving alkenone-derived SST data.

[58] We conclude that stronger El Niño activity does not start early on in the Last Glacial Maximum but only at $17 \mathrm{ka}$, which means 2-3 kyr later than would be expected from model results. The Late Glacial and early Holocene in Peru are characterized by centennial-scale variability of drier (less El Niño activity) and wetter (more El Niño activity) periods. Dry conditions prevailed during the beginning Younger Dryas as suggested by the Zebiak and Cane [1987] model. After $12.6 \mathrm{ka}$, ENSO sharply changed to stronger El Niño activity for the rest of the Younger Dryas. An early Holocene maximum of El Niño activity is followed by weak El Niño activity during the middle Holocene period $(8-5.6(5.2) \mathrm{ka})$. Maximum El Niño activity with thickest El Niño flood deposits occurred during the second and third millennium before the present. The strongest of the El Niño flood events recurred with a 60-80 year periodicity within the last $15 \mathrm{kyr}$. During the last millennium, El Niño activity resembles the global temperature (or vice versa). Thus a major Holocene El Niño weakness during the late medieval period that must have cooled down large parts of the lower latitudes implies that the climate in medieval times can only be of limited use as an analogy in the recent discussion of climate change.

[59] Acknowledgments. This work was supported by the German Bundesministerium für Bildung und Forschung and the KIHZ project (BMBF grants 03G0147C and 01LG9911). We are very grateful for the comments of two reviewers, which greatly improved the manuscript. Georg Scheeder is thanked for technical assistance in alkenone preparation and Jill Weller for language editing.

\section{References}

Adams, B. J., M. E. Mann, and C. M. Ammann (2003), Proxy evidence for an El Niño-like response to volcanic forcing, Nature, 426, $274-278$.

Allan, R. J. (2000), ENSO and climatic variability in the past 150 years, in El Niño and the Southern Oscillation-Multiscale Variability and Global and Regional Impacts, edited by H. F. Diaz and V. Markgraf, pp. 3-55, Cambridge Univ. Press, New York.

Andrus, C. F. T., D. E. Crowe, D. H. Sandweiss, E. J. Reitz, and C. S. Romanek (2002), Otolith $\delta^{18} \mathrm{O}$ record of mid-Holocene sea surface temperature in Peru, Science, 295, $1508-$ 1511.

Arntz, W., and E. Fahrbach (1991), El NiñoKlimaexperiment der Natur, 263 pp., Springer, New York.

Baker, P. A., G. O. Seltzer, S. C. Fritz, R. B. Dunbar, M. J. Grove, P. M. Tapia, S. L. Cross, H. D. Rowe, and J. P. Broda (2001), The history of South American tropical precipitation for the past 25,000 years, Science, 291, 640643.
Beaufort, L., T. de Garidel-Thoron, A. C. Mix, and N. G. Pisias (2001), ENSO-like forcing on oceanic primary production during the late Pleistocene, Science, 293, 2440-2444.

Berger, A. (1978), Long-term variations of daily insolation and Quaternary climatic changes, J. Atmos. Sci., 35, 2362-2367.

Bjerknes, J. (1969), Atmospheric teleconnections from the equatorial Pacific, Mon. Weather Rev., 97, 163-172.

Boto, K. G., and J. S. Bunt (1978), Selective excitation fluorometry for determination of chlorophylls and pheophytins, Anal. Chem., 50, 392-395.

Briffa, K. R., T. J. Osborn, F. H. Schweingruber, I. C. Harris, P. D. Jones, S. G. Shiyatov, and E. A. Vaganow (2001), Low-frequency temperature variations from a northern tree ring density network, J. Geophys. Res., 106, 2929-2941.

Chen, R. F., Y. Jiang, and M. Zhao (2000), Solidphase fluorescence determination of chlorins in marine sediments, Org. Geochem., 31, $1755-1763$
Clement, A. C., and M. Cane (1999), A role for the tropical Pacific coupled ocean-atmosphere system on Milankowitch and millennial timescales. Part I: A modeling study of tropical Pacific variability, in Mechanisms of Global Climate Change at Millennial Time Scales, vol. 112 , edited by P. U. Clark, R. S. Webb, and L. D. Keigwin, pp. 363-371, AGU, Washington, D. C.

Clement, A. C., R. Seager, M. A. Cane, and S. E. Zebiak (1996), An ocean dynamical thermostat, J. Clim., 9, 2190-2196.

Clement, A. C., R. Seager, and M. A. Cane (1999), Orbital controls on the El Niño/Southern Oscillation and the tropical climate, Paleoceanography, 14, 441-456.

Clement, A. C., M. A. Cane, and R. Seager (2001), An orbitally driven tropical source for abrupt climate change, J. Climatol., 14, 2369-2375.

Cobb, K. M., C. D. Charles, H. Cheng, and R. L. Edwards (2003), El Niño/Southern Oscillation and tropical Pacific climate during the last millennium, Nature, 424, 271-276. 
Corrège, T., T. Delcroix, J. Récy, W. Beck, G. Cabioch, and F. Le Cornec (2000), Evidence for stronger El Niño-Southern Oscillation (ENSO) events in a mid-Holocene massive coral, Paleoceanography, 15, 465-470.

Crowley, T. J. (2000), Causes of climate change over the past 1000 years, Science, 289, 270277.

Crowley, T. J., and T. S. Lowery (2000), How warm was the Medieval warm period?, Ambio, 29, $51-54$.

DeVries, T. J., L. Ortlieb, A. Diaz, L. Wells, and C. Hillaire-Marcel (1997), Response, Determining the early history of El Niño, Science, 276, 965-966.

Diaz, H. F., and V. Markgraf (1992), El Niño, 476 pp., Cambridge Univ. Press, New York.

Diaz, H. F., and V. Markgraf (Eds.) (2000), El Niño and the Southern Oscillation-Multiscale Variability and Global and Regional Impacts, Cambridge Univ. Press, New York

Doose-Rolinski, H., U. Rogalla, G. Scheeder, A. Lückge, and U. von Rad (2001), High-resolution temperature and evaporation changes during the late Holocene in the northeastern Arabian Sea, Paleoceanography, 16, 358-367.

Dullo, W. C., B. Rein, A. Wolf, N. Biebow, K. Schaber, and F. Sirocko (2000), Core descriptions and reflectance spectra, in Cruise Report Sonne-147-Peru Upwelling, BGR Rep. 0120607-11672/00, pp. 102-119, Bundesanst. für Geowiss. und Rohst., Hannover, Germany.

Emeis, K.-C., and A. Dawson (2003), Holocene paleoclimate records over Europe and the North-Atlantic, Holocene, 13, 305-309.

Esper, J., E. R. Cook, and F. H. Schweingruber (2002), Low-frequency signals in long tree-ring chronologies for reconstructing past temperature variability, Science, 295, 2250-2253.

Fairbanks, R. (1992), Barbados sea level and Th/ $\mathrm{U}^{14} \mathrm{C}$ calibration, in IGBP PAGES Data Contrib. Ser. 92-020, World Data Cent.-A for Paleoclimatol., Boulder, Colo. (available at ftp:// ftp.ncdc.noaa.gov/pub/data/paleo/contributions by author/fairbanks $1990 /$ barbados_1990.txt)

Fontugne, M., P. Usselmann, D. Lavallée, M. Julien, and C. Hatté (1999), El Niño variability in the coastal desert of southern Peru during the mid-Holocene, Ouat. Res., 52, 171-179.

Grootes, P. M., M. Stuiver, J. W. C. White, S. Johnsen, and J. Jouzel (1993), Comparison of oxygen isotope records from the GISP2 and GRIP Greenland ice cores, Nature, 366, $552-$ 554.

Harris, P. G., M. Zhao, A. Rosell-Melé, R. Tiedemann, M. Sarnthein, and J. R. Maxwell (1996), Chlorin accumulation rate as a proxy for Quaternary marine primary production, Nature, $383,63-65$

Haug, G. H., K. A. Hughen, D. M. Sigman, L. C. Peterson, and U. Röhl (2001), Southward migration of the Intertropical Convergence Zone through the Holocene, Science, 293, $1304-1308$.

Hendy, E. J., C. A. Gagan, C. A. Alibert, M. T. McCullock, J. M. Lough, and O. J. Isdale (2002), Abrupt decrease in tropical Pacific sea surface salinity at the end of Little Ice Age, Science, 295, 1511-1514.

Imbrie, J., et al. (1992), On the structure and origin of major glaciation cycles: 1. Linear responses to Milankovitch forcing, Paleoceanography, 7, 701-738.

Jiang, N., J. D. Neelin, and M. Ghil (1995), Quasi-quadrennial and quasi-biennial variability in the equatorial Pacific, Clim. Dyn., 12, $101-112$.
Jones, P. D., T. J. Osborn, and K. R. Briffa (2001), The evolution of climate over the last millennium, Science, 292, 662-667.

Keefer, D. K., S. D. de France, M. E. Moseley, J. B. Richardson III, D. R. Satterlee, and A. Day-Lewis (1998), Early maritime economy and El Niño events at Quebrada Tacahuay, Peru, Science, 281, 1833-1835.

Kosok, P. (1965), Life, Land and Water in Ancient Peru, Long Island Univ. Press, New York.

Koutavas, A., and J. Lynch-Stieglitz (2003), Glacial-interglacial dynamics of the eastern equatorial Pacific cold tongue-Intertropical Convergence Zone system reconstructed from oxygen isotope records, Paleoceanography, 18(4), 1089, doi:10.1029/2003PA000894.

Koutavas, A., J. Lynch-Stieglitz, T. M. Marchitto, and J. P. Sachs (2002), El Niño-like pattern in ce age tropical Pacific sea surface temperature, Science, 297, 226-230.

Kudrass, H. (2000), Cruise report Sonne-147Peru upwelling, BGR Rep. 0120607-11672/00, Bundesanst. für Geowiss. und Rohst., Hannover, Germany.

Kukla, G. J., A. C. Clement, M. A. Cane, J. E. Gavin, and S. E. Zebiak (2002), Last interglacial and early glacial ENSO, Quat. Res., 58, $27-31$

Lamy, F., J. Kaiser, U. Ninnemann, D. Hebbeln, H. W. Arz, and J. Stoner (2004), Antarctic timing of surface water changes off Chile and Patagonian ice sheet response, Science, 304, 1959-1962.

Lea, D. W. (2004), The 100,000-yr cycle in tropical SST, greenhouse forcing, and climate sensitivity, J. Clim., 17, 2170-2179.

Lea, D. W., D. K. Pak, and H. J. Spero (2000), Climate impact of late Quaternary equatorial Pacific sea surface temperature variations, Science, 289, 1719-1724

Loubere, P. (2000), Marine control of biological production in the eastern equatorial Pacific Ocean, Nature, 406, 497-500.

Loubere, P. (2002), Remote vs. local control of changes in eastern equatorial pacific bioproductivity from the Last glacial maximum to the Present, Global Planet. Change, 35 , $113-126$.

MacAyeal, D. R. (1993), Binge/purge oscillations of the Laurentide Ice Sheet as a cause of the North Atlantic Heinrich events, Paleoceanography, 8, 775-784

Mann, M. E., and P. D. Jones (2003), Global surface temperatures over the past two millennia, Geophys. Res. Lett., 30(15), 1820, doi:10.1029/2003GL017814

Mann, M. E., R. S. Bradley, and M. K. Hughes (1999), Northern Hemisphere temperature during the past millennium: Inferences, uncertainties and limitations, Geophys. Res. Lett. $26,759-762$.

Mann, M. E., M. A. Cane, S. E. Zebiak, and A. Clement (2005), Volcanic and solar forcing of the tropical Pacific over the past 1000 years, J. Clim., in press.

Markgraf, V., and H. F. Diaz (2000), The past ENSO record: A synthesis, in El Niño and the Southern Oscillation-Multiscale Variability and Global and Regional Impacts, edited by H. F. Diaz and V. Markgraf, pp. 465-488, Cambridge Univ. Press, New York.

McGlone, M. S., A. P. Kershaw, and V. Markgraf (1992), El Niño/Southern Oscillation climatic variability in Australasian and South American paleoenvironmental records, in El Niño, Historical and Paleoclimatic Aspects of the Southern Oscillation, edited by H. F. Diaz and V. Markgraf, pp. 435-462, Cambridge Univ. Press, New York.

Moy, C. M., G. O. Seltzer, D. T. Rodbell, and D. M. Anderson (2002), Variability of El Niño/ Southern oscillation activity at millennial timescales during the Holocene epoch, Nature, 420, $162-165$

Núñez, L., M. Grosjean, and I. Cartajena (2002), Human occupations and climate change in the Puna de Atacama, Chile, Science, 298, 821 824.

Oppo, D. W., B. K. Linsley, Y. Rosenthal, S. Dannenmann, and L. Beaufort (2003), Orbital and suborbital climate variability in the Sulu Sea, western tropical Pacific, Geochem. Geophys. Geosyst., 4(1), 1003 , doi:10.1029/2001GC000260.

Ortlieb, L. (2000), The documented historical record of El Niño events in Peru: An update of the Quinn record (sixteenth through nineteenth centuries), in El Niño and the Southern Oscillation-Multiscale Variability and Global and Regional Impacts, edited by H. F. Diaz and V. Markgraf, pp. 207-295, Cambridge Univ. Press, New York.

Otto-Bliesner, B. L., E. C. Brady, S.-I. Shin, Z. Liu, and C. Shields (2003), Modeling El Niño and its tropical teleconnections during the last glacial-interglacial cycle, Geophys. Res. Lett. 30(23), 2198, doi:10.1029/2003GL018553.

Pahnke, K., R. Zahn, H. Elderfield, and M. Schulz (2003), 340,000-year centennialscale marine record of Southern Hemisphere climatic oscillations, Science, 301, 948-952.

Peterson, L. C., G. H. Haug, K. A. Hughen, and U. Röhl (2000), Rapid changes in the hydrologic cycle of the tropical Atlantic during the last Glacial, Science, 290, 1947-1951.

Philander, S. G. H. (1990), El Niño, La Niña, and the Southern Oscillation, 293 pp., Elsevier, New York.

Pieters, C. M. , and P. A. J. Englert (Eds.) (1993), Remote Geochemical Analysis: Elemental and Mineralogical Composition, Topics Remote Sens., vol. 4, 594 pp., Cambridge Univ. Press, New York.

Prahl, F. G., L. A. Muehlhausen, and D. L. Zahnle (1988), Further evaluation of longchain alkenones as indicators of paleoceanographic conditions, Geochim. Cosmochim. Acta, 52, 2303-2310.

Quinn, W. H. (1992), A study of southern Oscillation-related climate activity for A. D. $622-$ 1900 incorporating Nile River flood data, in El Niño, edited by H. F. Diaz and V. Markgraf, pp. 119-149, Cambridge Univ. Press, New York

Reimers, C. E., and E. Suess (1983), Spatial and temporal patterns of organic matter accumulation on the Peru continental margin, edited by E. Suess, in Coastal Upwelling, Its Sediment Record, NATO Conf. Ser. IV, vol. 10B, Sedimentary Records of Ancient Coastal Upwelling, pp. 311-345, Springer, New York

Rein, B. (2003), In-situ Reflektionsspektroskopie und digitale Bildanalyse - Gewinnung hochauflösender Paläoumweltdaten mit fernerkundlichen Methoden, Habilitation thesis, 104 pp. Univ. of Mainz, Mainz, Germany.

Rein, B., and F. Sirocko (2002), In-situ reflectance spectroscopy-Analysing techniques for high resolution pigment logging in sediment cores, Int. J. Earth Sci., 91, 950-954.(Erratum, Int. J. Earth Sci., 92, 143, 2003.)

Rein, B., A. Lückge, and F. Sirocko (2004), A major Holocene ENSO anomaly during the Medieval period, Geophys. Res. Lett., 31 , L17211, doi:10.1029/2004GL020161. 
Reinhardt, L., H.-R. Kudrass, A. Lückge, M. Wiedicke, J. Wunderlich, and G. Wendt (2002), High-resolution sediment echo sounding off Peru: Late Quaternary depositional sequences and sedimentary structures of a current-dominated shelf, Mar. Geophys. Res., 23, $335-351$.

Repeta, D. J., and R. B. Gagosian (1984), Transformation reactions and recycling of carotenoids and chlorins in the Peru upwelling region, Geochim. Cosmochim. Acta, 48 , $1265-1277$.

Repeta, D. J., and R. B. Gagosian (1987), Carotenoid diagenesis in recent marine sediments I. The Peru continental shelf $\left(15^{\circ} \mathrm{S}, 75^{\circ} \mathrm{W}\right)$, Geochim. Cosmochim. Acta, 51, 1001-1009.

Rittenour, T. M., J. Brigham-Grette, and M. E. Mann (2000), El Niño-like climate teleconnections in New England during the late Pleistocene, Science, 288, 1039-1042.

Rodbell, D. T., G. O. Seltzer, D. M. Anderson, M. B. Abbott, D. B. Enfield, and J. H. Newman (1999), An 15,000-year record of El Niño-driven alluviation in southwestern Ecuador, Science, 283, 516-520.

Rosenthal, Y., D. Oppo, and B. K. Linsley (2003), The amplitude and phasing of climate change during the last deglaciation in the Sulu Sea, western equatorial Pacific, Geophys Res. Lett., 30(8), 1428, doi:10.1029/ 2002GL016612.

Sandweiss, D. H., J. B. Richardson, E. J. Reitz, H. B. Rollins, and K. A. Maasch (1996), Geoarchaeological evidence from Peru for a 5000 years B. P. onset of El Niño, Science, $273,1531-1533$

Sandweiss, D. H., J. B. Richardson III, E. J Reitz, H. B. Rollins, and K. A. Maasch (1997), Response: Determining the early history of El Niño, Science, 276, 966-967.

Sandweiss, D. H., K. A. Maasch, R. L. Burger, J. B. Richardson III, H. B. Rollins, and A. Clement (2001), Variation in Holocene El Niño frequencies: Climate records and cultural consequences in ancient Peru, Geology, 29, 603-606.
Scheidegger, K. F., and L. A. Krissek (1982), Dispersal and deposition of eolian and fluvial sediments off Peru and northern Chile, Geol. Soc. Am. Bull., 93, 150-162.

Shulmeister, J. (1999), Australasian evidence for mid-Holocene climate change implies precessional control of Walker circulation in the Pacific, Ouat. Int., 57/58, 81-91.

Shulmeister, J., and B. G. Lees (1995), Pollen evidence from tropical Australia for the onset of an ENSO-dominated climate at c. $4000 \mathrm{BP}$ Holocene, 5, 10-18.

Siddall, M., E. J. Rohling, A. Almogi-Labin C. Hemleben, D. Meischner, I. Schmelzer, and D. A. Smeed (2003), Sea-level fluctuations during the last glacial cycle, Nature, 423, 853-858.

Skilbeck, C. G., I. Goodwin, M. Gagan, M. Watson, and I. W. Aiello (2004), Highresolution palaeo-El Niño records from Peru continental margin, paper presented at 32nd International Geological Congress, Int. Union of Geol. Sci., Florence, Italy, 20-27 Aug.

Stuiver, M., and P. J. Reimer (1993), Extended 14-C data base and revised CALIB 3.0 14-C age calibration program, Radiocarbon, 35, 215-230.

Stuiver, M., P. J. Reimer, E. Bard, J. W. Beck, G. S. Burr, K. A. Hughen, B. Kromer, G. McCormac, J. van der Plicht, and M. Spurk (1998), INTCAL98 radiocarbon age calibration, 24,000-0 cal BP, Radiocarbon, 40, $1041-1083$

Suess, E., and R. von Huene (1990), Scientific Results-Leg 112, Ocean Drill. Program, College Station, Tex.

Suess, E., L. D. Kulm, and J. S. Killingley (1987), Coastal upwelling and a history of organic rich mudstone deposition off Peru in Marine Petroleum Source Rocks, edited by J. Brooks and A. J. Fleet, Geol. Soc. Spec. Publ. London, 26, 181-197.

Torrence, C., and G. P. Compo (1998), A practical guide to wavelet analysis, Bull. Am. Me teorol. Soc., 79, 61-78.

Tudhope, A. W., C. P. Chilcott, M. T. McCulloch, E. R. Cook, J. Chappell, R. M. Ellam, D. W.
Lea, J. M. Lough, and G. B. Shimmield (2001), Variability in El Niño-Southern Oscillation through a glacial-interglacial cycle, Science, $291,1511-1517$.

Verschuren, D., K. R. Laird, and B. F. Cumming (2000), Rainfall and drought in equatorial East Africa during the past 1,100 years, Nature, $403,410-414$

Wells, L. E. (1990), Holocene history of the El Niño phenomenon as recorded in flood sediments of northern coastal Peru, Geology, 18 , $1134-1137$

Wells, L., and J. S. Noller (1997), Response: Determining the early history of El Niño, Science, 276, 966.

Welschmeyer, N. A. (1994), Fluorometric analysis of chlorophyll a in the presence of chlorophyll b and pheopigments, Limnol. Oceanogr., 39, 1985-1992.

Wolf, A. (2003), Zeitliche Variation im peruanischen Küstenauftrieb seit dem Letzten Glazialen Maximum-Steuerung durch globale Klimadynamik, doctoral thesis, 88 pp., Univ. Kiel, Kiel, Germany.

Wolf, A., N. Biebow, and C. Dullo (2001) Die Entwicklung des Auftriebsgeschehens vor Peru seit dem letzten Glazial, paper presented at Statusseminar FS Sonne 2001, Bundesminist. für Bild. und Forsch., Hannover, Germany.

Zebiak, S. E., and M. A. Cane (1987), A model El Niño-Southern Oscillation, Mon. Weather Rev., 115, 2262-2278.

W.-C. Dullo, IFM-Geomar, Wischhofstr. 1-3, D-24148 Kiel, Germany.

A. Lückge, L. Reinhardt, and A. Wolf, Bundesanstalt für Geowissenschaften und Rohstoffe (BGR), Stilleweg 2, D-30655 Hannover, Germany.

B. Rein and F. Sirocko, Institut für Geowissenschaften, Johannes Gutenberg Universität Mainz, Becherweg 21, D-55099 Mainz, Germany. (brein@uni-mainz.de) 


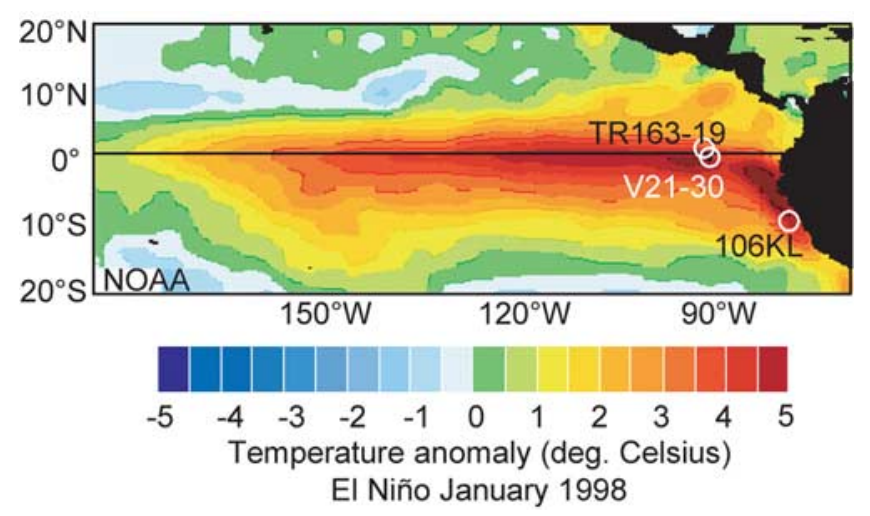

Figure 2. Sea surface temperature anomalies during the 1997/1998 El Niño (http://www.cdc.noaa.gov/ map/clim/sst_olr/el_nino_anim.shtml) and core locations of $106 \mathrm{KL}$ off Peru and eastern equatorial Pacific sites V21-30 [Koutavas et al., 2002] and TR163-19 [Lea, 2004]. 